University of Rhode Island

DigitalCommons@URI

Open Access Master's Theses

1995

\title{
A COMPARATIVE ANALYSIS OF THE EFFECTIVENESS OF DRUGGED DRIVING VS. DRUNK DRIVING
}

Ernest DiFazio Jr.

University of Rhode Island

Follow this and additional works at: https://digitalcommons.uri.edu/theses

\section{Recommended Citation}

DiFazio, Ernest Jr., "A COMPARATIVE ANALYSIS OF THE EFFECTIVENESS OF DRUGGED DRIVING VS. DRUNK DRIVING" (1995). Open Access Master's Theses. Paper 243.

https://digitalcommons.uri.edu/theses/243

This Thesis is brought to you for free and open access by DigitalCommons@URI. It has been accepted for inclusion in Open Access Master's Theses by an authorized administrator of DigitalCommons@URI. For more information, please contact digitalcommons-group@uri.edu. 


\section{MASTER OF SCIENCE THESIS \\ $\mathrm{OF}$ \\ ERNEST DIFAZIO, JR.}

\section{APPROVED:}

Thesis Committee

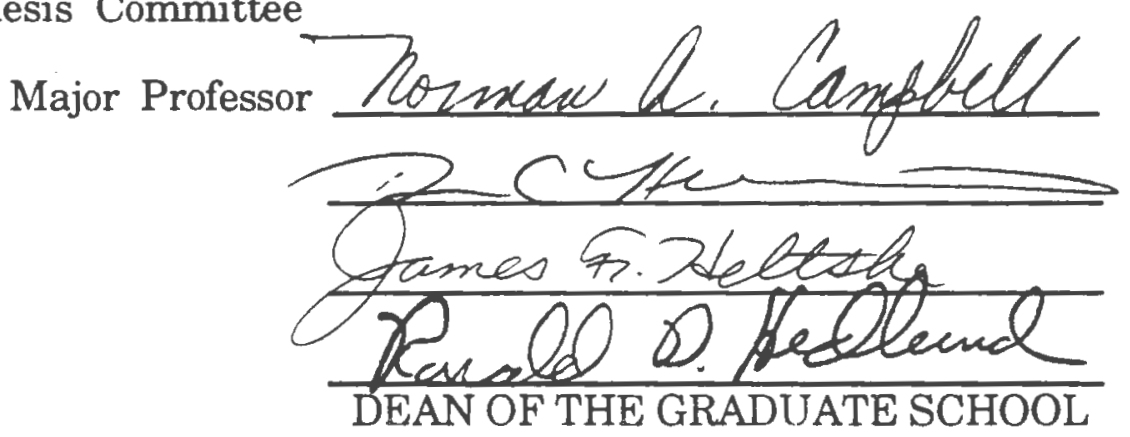

UNIVERSITY OF RHODE ISLAND 
A COMPARATIVE ANALYSIS OF THE EFFECTIVENESS OF DRUGGED DRIVING VS. DRUNK DRIVING

BY

ERNEST DIFAZIO, JR.

\begin{abstract}
A THESIS SUBMITTED IN PARTIAL FULFILLMENT OF THE REQUIREMENTS FOR THE DEGREE OF

MASTER OF SCIENCE

IN

PHARMACY ADMINISTRATION
\end{abstract}

UNIVERSITY OF RHODE ISLAND

1995 


\begin{abstract}
This paper reviews the relevant state statutes dealing with driving under the influence of drugs and alcohol on enforcement standards, which reveals some problems with the effectiveness of the drug provisions. In an effort to strengthen provisions in one state, the death certificates of 150 persons who died in motor vehicle accidents in the decade of the 1980 s to date were reviewed to determine serum levels of any drugs revealed in the autopsy. These data have been analyzed in light of appropriate statutory prohibitions against driving under the influence of drugs or alcohol. The potential for driver impairment by drugs has not been recognized--as in the case of alcohol. Although, most state statutes concerning driving under the influence (DUI) include both alcohol and drugs, specific serum concentration standards have been developed only for alcohol.

Concomitant drug use and the resulting driver impairment is detailed in the law, and the law does state drug use is causing impairment, but there are no levels for drug impairment to enforce. While this is recognized by some state legislatures, it is not enforced uniformly.
\end{abstract}




\section{ACKNOWLEDGMENTS}

I would like to show my sincerest and most emotional acknowledgments to some of the dearest people without whom this project would have never been started nor completed. First, and foremost, I would like to thank Dr. Norman A. Campbell for his mentor role and "father-like" advice and leadership. I would like to thank Dr. Albert H. Taubman, for his "real world" answers--they humbled me. In memory, I would like to thank Charles Hachadorian for his expertise in the enforcement field. I would like to thank Thomas C. Davis for doing all the dirty work in the Medical Examiners office collecting data. I would like to thank Dr. William Q. Sturner and Diane A. Tellier for all their help and support. I would like to thank all the faculty and staff in the Pharmacy Administration program. I would like to thank Professor Dennis Hilliard and Dr. Joan M. Lausier for bailing me out at my worst moment. I would like to thank my girlfriend, Karen Cameron, for pushing me everyday to get this thesis finished! I would like to thank Lisa Marzilli, who taught me how to be productive by utilizing all 24 hours of each day. Lastly, I would like to thank my mother for giving me the strength and determination to do my very best at whatever I do. 


\section{PREFACE}

The problem of driver impairment due to alcohol has been well documented. State statutes make reference to impairment due to other

drugs as well. The lack of clearly developed and defined standards relative to drugged driving has resulted in those statutes being ineffectual. Drugged driving is prevalent. Blood levels of numerous drugs are impairing people in today's society and there is a need to legally determine at what extent these blood levels are causing impairment. With proper legal action and intervention--such as education-- standards may be developed and defined relative to drugged driving.

This study will review efforts by other researchers as well as federal and state agencies to develop and implement drugged driving standards. Using those efforts as a baseline, models should be created to assist states in implementing a process for standards development and use. The results will be useful to state and federal law enforcement agencies in their efforts to prosecute drivers impaired by drugs and to educate prospective abusers about engaging in such behaviors.

In the interim, a drug recognition expert's (DRE's) testimony may be accepted by the courts while drugged driving standards are developed. A drug recognition expert is trained to identify and differentiate between classes of drug impairment. 


\section{TABLE OF CONTENTS}

PAGE

ABSTRAC'T

ii

ACKNOWLEDGEMENTS

iii

PREFACE

iv

TABLE OF CONTENTS

v

LIST OF TABLES

vii

METHODOLOGY

viii

INTRODUCTION

1

STATEMENT OF THE PROBLEM

2

REVIEW OF THE LITERATURE

4

RESULTS OF THE RHODE ISLAND DEPARTMENT

11

OF DRUG CONTROL SURVEY

ANALYSIS OF THE RHODE ISLAND MEDICAL EXAMINER'S 14 DATA

ALCOHOL MODEL

19

BREATH TEST FOR THE DETERMINATION OF ALCOHOL

20 IN BLOOD THEORY 
REFERENCES

APPENDIX

A. MOTOR VEHICLE OFFENSES

B. AN ACT TO DRIVING UNDER THE INFLUENCE OF 52 LIQUOR OR DRUGS

C. AN ACT RELATING TO MOTOR VEHICLE OFFENSES

D. UPDATED ACTION ON DRE PROGRAMS 


\section{LIST OF TABLES}

TABLE

PAGE

i. DRUGS FOUND IN LITERATURE

2. RETROSPECTIVE MEDICAL EXAMINER'S DATA

BY YEAR

3. THRESHOLD DRUG CONCENTRATIONS FOR MEDICAL EXAMINER'S DATA FOR PRESUMPTIVE IMPAIRMENT

4. THRESHOLD DRUG CONETRATIONS FOR PRESUMPTIVE 31 IMPAIRMENT--DRUG IMPAIRMENT CORRELATION PLASMA/BLOOD, SALIVA AND URINE 


\section{METHODOLOGY}

\section{A. REVIEW OF STATE LAWS}

With the assistance of the Rhode Island Department of Health's Division of Drug Control, this paper is set out to analyze not only Rhode Island State law, but to also review 36 state laws across the country as well.

\section{B. DATA COLLECTION}

Research of retrospective data from the Rhode Island Medical Examiner's office was done dealing with a full decade of death certificates from Rhode Island highway fatalities involving drugs. Due to poor record keeping and the small number of death certificates involving drugs in certain years, only four years of the most prevalent data was used. 


\section{INTRODUCTION}

Many motorists are driving under the influence of drugs at this very moment and are not even aware that they are. Drugs other than or in addition to alcohol are causing numerous motor vehicle accidents in the state of Rhode Island and at the present time it is difficult to detect this unlawful act. This study is set out to determine if there is a causal relationship between drugs other than alcohol and motor traffic accidents. Alcohol, unlike other drugs, is one substance that has been extensively studied by many researchers to determine its role in motor vehicle impairment. A standard has been devised for alcohol impairment, e.g., $0.10 \%$ by weight in most states. $(0.08 \%$ in some states and $0.05 \%$ in some European countries) For drugs it is a more complex situation than for alcohol. There are a variety of drug classes with different primary and secondary effects which can cause impairment.

There have been extensive drug reviews and laboratory studies which have shown impaired driving performance for a variety of drugs. Although impairment on driving related tasks can be shown for a drug, the extent that this impairment leads to auto accidents cannot be inferred without ascertaining the frequency that these drugs were found in drivers in general. Determining the extent that drug-impaired performance increases crash risk is necessary in order to establish the relationship of drug to highway safety.(Stewart, et.al.) 


\section{STATEMENT OF THE PROBLEM}

The operator of a motor vehicle is required to have numerous motor vehicle skills coupled with alertness, perception, judgment, coordination and a sense of care and caution. Some, or all, of these safe driving requirements may be compromised in persons taking drugs due to their intended effects or side effects. Concern about the potentially deleterious effects of drugs which suppress the central nervous system (CNS) function on the ability to drive an automobile has been repeatedly expressed. (Jick) Although most state statutes concerning driving under the influence include both alcohol and drugs, specific blood level concentration standards have been developed only for alcohol. Alcohol is the only substance for which there is a standard blood level for impairment. (see Appendix A)

Concomitant use of alcohol and drugs while driving can lead to driver impairment, and this is not recognized by state legislatures. Information for drug levels and their effects on driver impairment does not exist. (Miller) What is not known to the general public is that the chemistry and pharmacology of drugs are generally more complex than alcohol. (Miller) In order to determine a causal relationship between drugs other than alcohol and traffic accidents, the impairing drug(s) need to be thoroughly researched. For drugs, the chemical interactions within the living body are less understood, highly variable and difficult to study or explain. (Miller) Drugged Driving is prevalent. Blood levels of numerous drugs are impairing individuals in today's society and there is a need to determine at what concentration these blood levels are causing impairment. Studies are constantly performed on drugs to determine 
therapeutic performance at certain blood levels, however, no significant data are available to determine at what blood level impairment is seen. The relationship hetween dosage levels of drug, driving impairment, and increased crash risk is difficult to determine.

Currently, the National Highway Traffic Safety Administration (NHTSA) reports that traffic accidents and driving under the influence of drugs (DUID) arrest data both report that $10-22 \%$ of the drivers use potentially impairing drugs. Therefore, this study is designed to show that with the proper legal action and intervention, standards may be developed and defined relative to drugged driving. To date, there has been one successful prosecution of a vehicle operator charged with driving under the influence of drugs as set forth in the Rhode Island statutory language.

With the assistance of the Rhode Island Department of Health's Division of Drug Control (DDC), a survey of all 50 states was conducted in 1984, pertaining to the drugged driver. The main objective was to see if individual states had "drugged driving" statute(s) pertaining to driving under the influence of drugs other than alcohol, and if any of the statutes define drug levels. Likewise, a study was conducted at the Rhode Island Medical Examiner's office by our workforce team, to show retrospective data on death certificates that were involved in motor vehicle accidents with drug substances in their blood. 


\section{REVIEW OF THE LITERATURE}

The literature review focuses on the influence of drugs in causing an impairment, thus hindering driver performance, as well as legal issues. In order to determine a causal relationship between drugs other than alcohol and traffic accidents, we need to identify the potentially hazardous drugs and to correlate them with specific and definitive driving laws. Studies to determine the frequency with which drugs are involved in either fatal or non-fatal automobile accidents are limited; however enough information has been documented to indicate the impact of driving under the influence of drugs in the United States. Studies of the incidence of drug use in the general population indicate that drugs have become an important factor in the automobile driving population. An editorial in Traffic Laws Commentary (1965) presents general figures prepared by Smith, Kline, and French in 1963. It states that at any time, $10-20 \%$ of the general population was using a prescribed drug. A survey conducted by Mellinger et al. (1968) reported the frequency of drugs in 3,409 routine drinking driver investigations in South Clara County, California during 1968. Seven-hundred and five or $21 \%$ of the cases involved drug occurrences. There were one-hundred and seven different drugs which fell into twenty different categories which involved prescribed and over-thecounter compounds.

A study conducted by Woodhouse(1972) of the Midwest Research Institute sponsored by the U.S. Department of Transportation determined the incidence of drugs in fatally injured drivers. One-hundred and ninetyone biological samples were obtained from special Alcohol Safety Action 
Project areas throughout the United States. Samples were sent in by coroners and medical examiners. It was determined that $24 \%$ of the specimens submitted contained drugs other than alcohol.

The prevalence of marijuana use in general driving population and its impact on highway safety are not known. However, recent surveys disclose considerable cannabis use in all age groups, while other data suggest that driving under the influence of this drug is wide-spread (Zimmerman, et al.). A study conducted by Zimmerman et al. (1983) reported that the major psychoactive cannabinoid in marijuana, delta-9tetrahydrocannabinal (THC) was measured in 1792 randomly selected blood specimens from erratic motorists arrested for impairment who submitted to blood alcohol sampling. Of these specimens, $14.4 \%$ were positive for THC (greater or equal to $5.5 \mathrm{ng} / \mathrm{ml}$ ). In those erratic driver specimens negative for alcohol, THC positives rose to $23 \%$. Drivers who used marijuana covered a broad age range.

The effects of barbiturates on alertness make their use by drivers especially hazardous. Laboratory studies and driving or driving simulator studies have shown that moderate doses of barbiturates severely degrade performance of critical driving skills. Performance of psychomotor skills such as vehicle handling and reaction time, perceptual skills, tracking abilities, oculomotor functions, and information processing skills were all impaired by barbiturates(Sharma, 1976).

In a study conducted by Garriott et al. (1976) barbiturates were detected, either alone or in combination with other barbiturates or other drugs in 55 of 135 drivers $(40.7 \%)$ arrested for driving under the influence of drugs in Dallas County, Texas. The large majority of these barbiturates detected were intermediate acting. Phenobarbital was detected in only six 
cases (44\% of all drivers, $9.5 \%$ of all barbiturates detected.) Of the barbiturates detected $(n=63)$, secobarbital/amobarbital combinations $(n=23)$ and secobarbital alone $(n=16)$ comprised the majority.

A study conducted by Gengo et al, concluded that diphenhydramine does cause driver impairment. The time-course of diphenhydramine concentrations and effects on both mental performance and subjective feelings of drowsiness were assessed in 15 healthy subjects. Subjects received single oral doses of diphenhydramine $(50 \mathrm{mg})$. and placebo in this double blind crossover study. Diphenhydramine plasma concentrations and central nervous system actions were assessed for 24 hours after each treatment. Cognitive impairment was assessed with an automobile driver simulator and digit symbol substitution scores, whereas drowsiness was self-assessed on a visual analog scale. Diphenhydramine produced significant feelings of drowsiness for up to 6 hours after the dose, whereas significant mental impairment was apparent for only 2 hours. Despite the difference in duration of these effects, drowsiness and mental impairment have parallel slopes when effects are related to diphenhydramine concentrations. This data suggest that although the apparent diphenhydramine thresholds to produce drowsiness are lower ( 30.4 to 45 $\mathrm{ng} / \mathrm{ml}$ ) than those needed to produce mental impairment (58.2 to 74.4 $\mathrm{ng} / \mathrm{ml}$ ) these effects have profiles consistent with their being manifestations of the same pharmacological effect.

The role of drugs in traffic accidents is becoming more and more prevalent as time goes on. A study done by Honkanen et al., summarized results of serum samples from 201 drivers who were presented at emergency departments within six hours after being injured in a road accident and from 325 control drivers selected randomly at pectrol stations 
were screened for drugs by combined thin-layer and gas chromatography Blood alcohol concentrations were also measured, and a questionnaire on the subjects' state of health and use of drugs administered. An interview of 30 patients (15\%) and 44 controls (13\%) said that they had taken drugs in the previous 24 hours. Four patients (2\%) and six controls (2\%) said that they had taken psycotropic drugs, but serum analysis detected psychotropic drugs in 10 patients $(5 \%)$ and eight controls (2.5\%). Diazepam was found in 16 of the 18 subjects in whom psychotropic drugs were detected. Alcohol was detected in 30 patients (15\%) and three controls (1\%).

Sedating drugs and automobile accidents leading to hospitalization has become a major concern to many healthcare professionals. A study conducted by Jick et al., showed that the use of central nervous system depressant drugs among 244 people hospitalized for injures suffered in an automobile accident was similar for drivers presumed at fault for the accident when compared with the other drivers and passengers. It was only slightly higher in the three groups than it was in the population at large. The absence of an impairment association in this population might be related to the warnings given to people filing prescriptions for these drugs. Careful instruction of patients receiving CNS depressant drugs about the potential increased risk of automobile accidents well have contributed to the absence of a material difference in accident rates between users and non-users in the current study and may be useful in preventing future accidents.

A good source of information from published studies, was a study of data collected from all DUID, including both fatalities and motor vehicle accident cases, in the state of Georgia over the period of 1978-1981, which revealed 974 blood specimens that were found positive for methaqualone, all 
in excess of $0.5 \mathrm{ug} / \mathrm{ml}$. Of these, $536(55 \%)$ contained methaqualone alone in excess of $1.0 \mathrm{ug} / \mathrm{ml}$. (McCurdy et al., 1978).

A study of 440 male drivers aged 15-34, killed in automobile crashes in California during 1982-83, showed two or more drugs present in $43 \%$, cannabinoids in $37 \%$, and alcohol in $70 \%$. (Williams et al., 1984).

The class of minor tranquilizers-psychotropic drugs--is most likely to be found in combined use with alcohol among the general population Many of the general population are still unaware that this class of drugs can increase the effects of alcohol on performance skills and alertness. Linnoila and Mattila (1973) found increased deficits in collision frequency, ignoring of instruction and steering errors in a driving simulator. Linnoila and Hakkinen (1974) using professional drivers of considerable experience reported similar results. Diazepam-alcohol combination produced greater impairment of driving skills than either diazepam or alcohol alone. Neuteboom and Zweipfenuing (1984) evaluated the use of therapeutic agents by drivers suspected of driving under the influence of alcohol. In reviewing 40,000 case reports, the authors found $9.7 \%$ of the drivers (1,681 cases) indicated they used drugs in combination with alcohol. For the drugs reported, $50 \%$ were drugs potentially hazardous to highway safety. Of the 1,681 driver-risk cases, 1,104 reported the use of diazepam, with 123 cases reporting multiple benzodiazepine usage.

Recent data (Valentour 1988) on blood samples obtained from the state of Virginia drivers submitted by police for DUID testing has shown confirrned positives THC/THCA in $32 \%, \mathrm{PCP}$ in $29 \%$, and cocaine/benzoylecgonine in $9.4 \%$ of these cases. Diazepam/nordiazepam has been seen in $3.4 \%$ of the DUID cases with barbiturates or opiates both at 
3-4 \% frequency. All positive results were confirmed and quantitated by GC/MS.

Cimbura et al. (1982) presented perhaps the most definitive evaluation of drug incidence in fatally injured drivers in Ontario, Canada over a one year period. Rather than limiting the scope of the study to a few drugs, Cimbura listed all drugs along with their concentrations and also made an attempt to categorize their effects. Blood and urine samples were collected from 401 drivers, and screened for over 90 drugs. Drugs, other than alcohol, were reported in $26 \%$ of the drivers, but a number of drugs were not psychoactive, such as aspirin and acetaminophen. Psychoactive drugs were found in $9.5 \%$ of the drivers, most in combination with alcohol. The most frequently detected drugs were THC (3.7\%) and diazepam (3\%).

Based on this data, law enforcement agencies are in need of assistance in combating drunk/drugged driving. It is well known that alcohol and driving are a popular combination. From the literature, we see that the combination of drugs and driving has become just as popular. The problem with the latter situation is that many of the drugs involved in drugged driving are illegally consumed, which makes it difficult to determine which drug is being used. Therefore, one solution to assist the law enforcement agencies is the Drug Recognition Expert (DRE) training program. (See table 1 for literature data summary) 
TABLE 1:

DRUGS FOUND IN LITERATURE DATA:

CLASS

ILLICIT

CANNABIS

Marijuana(with alcohol)

Marijuana (w/o alcohol)

Cannabinoids

Marijuana

Methaqualone

\section{$\underline{\text { SCHEDULED }}$}

\section{SEDATIVE/HYPNOTIC}

Phenobarbital

Barbiturate combination

Secobarbital

\section{TRANQUULIZER}

Diazepam

Benzodiazepine comb.

Diazepam
\#DETECTEDTOTALCASES PERCENTAGE(\%)

259/792

$14.4 \%$

413/1792

$23 \%$

$163 / 440$

$37 \%$

$15 / 401$

$3.7 \%$

$538 / 974$

$55 \%$
$6 / 135$

23/135

$16 / 135$
$4.4 \%$

$17 \%$

$11.8 \%$
1104/1681

$123 / 1681$

$12 / 401$
$65.6 \%$

$7.3 \%$

$3 \%$ 


\section{RESULTS OF THE RHODE ISLAND DEPARTMENT OF DRUG CONTROL SURVEY}

Out of the states surveyed, only 36 responses were received, not including multiple agency responses, with each one responding that they did not have any blood standards for drugs. Some indicated that a blood test would be conducted in those circumstances where the operator appeared to be impaired, and the tests for alcohol were negative or below legal limits. Therefore, with no such blood standards established, in a court of law, there is no practical proof of "drugged driving."

The state of Idaho reported that the testing of blood specimens from drivers and adult pedestrians killed in motor vehicle accidents for "alcohol, narcotics, and other dangerous drugs" found common prescription tranquilizers in the blood samples, but reported that there is very little information concerning the possible relationship between drugs and accidents.

Eighteen states responded that they did utilize a preliminary breath test method for alcohol, but none to test for drugs initially. It was indicated that the state of Arkansas has a grant for identifying impaired drivers using drugs other than alcohol. To date, Arkansas reports that the number of blood screenings requested for this purpose is one out of 1,104 cases.

Included with the response from the state of California, was a Physical Evidence Bulletin, which indicated that an analysis for drugs may be requested in cases where the alcohol level is $0.10 \%$ or less, and could be conducted only after the blood alcohol results have been reviewed by the 
district attorney to establish a need for a toxicological analysis. It was indicated in this Bulletin, that at least two 10 milliliter tubes of blood, or one 15 milliliter tube and at least 20 milliliters of urine should be submitted for toxicological analysis, with the sample containers agitated to ensure mixing of the preservatives and refrigerated until analyzed. It was indicated that at least 20 milliliters of blood and/or urine is required for a complete analysis of drugs and cannabinoids, while 10 milliliters is required for cannabinoids alone. These results are interpreted according to pharmacological effects, and to their being present in: (1) a trace amount; (2) a therapeutic level; (3) a toxic level, or (4) a lethal level, with the results interpreted as to how normal individuals would be affected by these levels of drugs.

The state of Delaware reported that even though they do not have established blood standards for drugs, they do have a "D.U.I. Law", which covers driving under the influence of alcohol, or of any drug or any combination of drugs and/or alcohol. The D.U.I. Law of October, 1982, established that taking or not taking of preliminary breath testing (P.B.T.) would have no bearing on the Implied Consent Law. If an officer has probable cause to believe an operator is intoxicated and receives a negative or very low BAC (Blood Alcohol Concentration), he/she would take the suspect to the hospital for a blood test to check for the presence of drugs instead of going to troop for a breath test.

The state of Georgia reports that, like the rest of the states, it has no set standards for drugged driving. However, they do have data, on driving under the influence of all barbiturates, with the exception of phenobarbital. If they find a drug in the blood, they often charge the individual with driving under the influence. They report that the drug concentrations 
present are consistent with driving under the influence. In other cases, they admit that the effect is variable or that they do not have sufficient data and the case is judged solely on the police officers testimony and the analyzed results from the laboratory.

In the state of Ohio, they report that for drugs other than alcohol, it is necessary to perform an analysis to demonstrate that the drugs are present and are present in levels sufficient to demonstrate impairment. The state does this through the opinion portion of the toxicology reports on samples analyzed by the states laboratory. They follow the rule of thumb that if a single drug is present, it must be depressant in nature and in a concentration greater than the low-end level of therapeutic range for that drug. When the drug is synergistic with other drugs or alcohol that are present in the system, a triggering level of 0.03 alcohol (blood or breath) plus low-end level therapeutic concentration is considered being under the influence and the driver is impaired.

To summarize, it is the general consensus of the responding states that it is this absence of standards which has prevented the testing for drugs, thus limiting the states to the screening for alcohol. All the responding states were in agreement that driving under the influence of drugs, does impair the driving ability of the operator. 


\section{ANALYSIS OF RHODE ISLAND MEDICAL EXAMINER'S DATA}

To determine which drugs might be targeted initially in Rhode Island, research of data from Rhode Island's Medical Examiner's office was done dealing with a decade of death certificates on highway fatalities in Rhode Island involving drugs.

During each year from 1985 to 1988 over 300 death certificates were reviewed of persons who died in motor vehicle accidents. These death certificates were examined to determine which drugs or substances were found in the blood stream upon autopsy.

In 1985 , there was a total of 115 traffic related deaths. At the end of the year, December 31, 1985, there was a total of 61 driver-related deaths, of that 61,12 tested positive for drugs or substances with and without the combination of alcohol. The data also shows that there were several combinations of drugs, at the time of testing.

YEAR: 1985

TOTAL DEATHS TRAFFIC RELATED: 115

TOTAL DEATHS TESTED POSITIVE FOR DRUGS/SUBSTANCES: 12

MALE: 9

FEMALE:3

DRUGS “POSITIVE” AT TESTING TIME PER AUTOPSY: 12

THC: 9

COCAINE: 1

PHENOBARBITAL: 1

LIDOCAINE: 1 
In 1986 , there were a total of 124 traffic related deaths. Of that 124,72 deaths were drivers, of that 72,7 tested positive for drugs or substances other than alcohol.

YEAR: 1986

TOTAL DEATHS TRAFFIC RELATED: 124

TOTAL DEATHS TESTED POSITIVE FOR DRUGS/SUBSTANCES: 7

MALE: 5

FEMALE: 2

DRUGS "POSITIVE" AT TESTING TIME PER AUTOPSY: 7

THC: 2

COCAINE: 5

In 1987 , there were a total of 126 traffic related deaths. Of that 126 total, 78 were driver related, of that 78,11 of the drivers tested positive for drugs or substances other than alcohol.

YEAR: 1987

TOTAL DEATHS TRAFFIC RELATED: 126

TOTAL DEATHS TESTED POSITIVE FOR DRUGS/SUBSTANCES: 11

MALE: 9

FEMALE: 2

DRUGS “POSITIVE" AT TESTING TIME PER AUTOPSY: 11

THC: 3

COCAINE: 1

DIAZEPAM: 1

COMBINATIONS: COCAINE/VALIUM: 1

COCAINE/METHADONE: 1 
THC/DIAZEPAM/TEMAZEPAM: 1

COCAINE/THC: 1

CODEINE/PHENOBARBITAL: 1

CODEINE/THC/DIAZEPAM: 1

In the year 1988, there were a total of 125 traffic related deaths. Of that 125,93 were driver related, of that 93,12 tested positive for drugs and substances other than alcohol.

YEAR: 1988

TOTAL DEATHS TRAFFIC RELATED: 125

TOTAL DEATHS TESTED POSITIVE FOR DRUGS/SUBSTANCES: 12

MALE: 6

FEMALE: 6

DRUGS “POSITIVE” AT TESTING TIME PER AUTOPSY: 12

THC: 2

COCAINE: 2

BENADRYL: 1

CAFFEINE: 5

COMBINATIONS: THC/COCAINE: 1

BENZODIAZEPAM/AMPHETAMINE: 1

Therefore, the drug/drug categories that this study revealed should be the main focus of future research in this field. Produced below (Table 2) shows a summary of the R.I. Medical Examiner's data by year. Table 3 includes presumptive impairment levels of the most prevalent drug/drug classes found in the Rhode Island Medical Examiner's data. 
TABLE 2:

RETROSPECTIVE MEDICAL EXAMINER'S DATA BY YEAR:

\begin{tabular}{|l|l|l|l|l|}
\hline YEAR & $\begin{array}{l}\text { TOTAL } \\
\text { DEATHS } \\
\text { TRAFFIC } \\
\text { RELATED }\end{array}$ & $\begin{array}{l}\text { TOTAL } \\
\text { DRIVER } \\
\text { RELATED } \\
\text { DEATHS }\end{array}$ & $\begin{array}{l}\text { DRIVER'S } \\
\text { TESTING } \\
\text { POSITIVE } \\
\text { FOR DRUG } \\
\text { SUBSTANCES }\end{array}$ & $\begin{array}{l}\text { DRUG } \\
\text { SUBSTANCES }\end{array}$ \\
\hline 1985 & 115 & 61 & 12 & $\begin{array}{l}\text { THC } \\
\text { COCAINE } \\
\text { PHENOBARB } \\
\text { LIDOCAINE }\end{array}$ \\
\hline 1986 & 124 & 72 & 7 & $\begin{array}{l}\text { THC } \\
\text { COCAINE }\end{array}$ \\
\hline 1987 & 126 & 78 & 11 & $\begin{array}{l}\text { THC } \\
\text { COCAINE } \\
\text { DIAZEPAM } \\
\text { COMBINATI } \\
\text { ON }\end{array}$ \\
\hline 1988 & 125 & 93 & $\begin{array}{l}\text { THC } \\
\text { COCAINE } \\
\text { BENEDRYL } \\
\text { CAFFEINE } \\
\text { COMBINATI } \\
\text { ON }\end{array}$ \\
\hline
\end{tabular}


TABLE 3:

THRESHOLD DRUG CONCENTRATIONS FOR MEDICAL EXAMINER'S DATA FOR PRESUMPTIVE IMPAIRMENT:

\begin{tabular}{|l|l|}
\hline DRUG SUBSTANCE & $\begin{array}{l}\text { CONCENTRATIONS } \\
\text { (PLASMA / BLOOD) }\end{array}$ \\
\hline MARIJUANA & P $2 \mathrm{ng} / \mathrm{ml} \mathrm{B} \mathrm{ng} / \mathrm{ml}$ \\
\hline COCAINE & B $5.2 \mathrm{mg} / 1$ \\
\hline PHENOBARBITAL & P $60 \mathrm{ug} / \mathrm{ml}$ \\
\hline LIDOCAINE & P $5 \mathrm{ug} / \mathrm{ml}$ \\
\hline DIAZEPAM & P $150 \mathrm{ng} / \mathrm{ml}$ \\
\hline DIPHENHYDRAMINE & P $65 \mathrm{ng} / \mathrm{ml}$ \\
\hline
\end{tabular}

*P=Plasma $*$ B=Blood 


\section{ALCOHOL MODEL}

Although alcohol use among motor vehicle operators is well established, drug use is less well defined. Alcohol, unlike drugs in general is one substance which has been thoroughly studied by various researchers to determine its effects on driving impaired. Chemical tests for intoxication show the percent of alcohol in the individuals blood at the time the test was taken. This test does not show when the drinking was done; what type of beverage was consumed; the quantity of alcohol consumed; the period of time over which the alcohol was consumed; or anything else except the alcohol stored in the blood at that moment the test was performed. This information is exactly the information needed, for it gives the condition of the individual at the time tested. It is possible to use the results of chemical tests obtained from an individual in a series of tests at known time intervals, to calculate the total amount of alcohol in the system, and the approximate time of the last drink. Calculation of the total alcohol in the system at the time the test was given, is frequently used to refute or verify the too-familiar statement that an individual involved in an accident had only a "couple of beers". (DOH, DDC, 1991 Breath Alcohol-Analysis Program) 


\section{BREATH TESTS FOR THE DETERMINATION OF ALCOHOL IN BLOOD THEORY:}

The term "Breath-Test" is used to describe the determination of the concentration of ethyl alcohol in an individuals blood, by a quantitative chemical analysis for alcohol in an individuals breath, taken under controlled conditions.

Exhaustive scientific experimentation has proven that the breath in the lungs absorbs alcohol from the blood vessels in the walls of the lungs, and that the relationship of the alcohol in the blood to the alcohol in the breath is a constant ratio for any individual.

The breath analyzed must be lung air from the deep part of the lungs, and this air or breath is known as "alveolar breath". The alveolar breath is the air from minute air sacs (alveoli) which are the terminal ends of the smallest branches of the windpipe(trachea). The last quarter of the deep exhalation is alveolar air. It has been established, that for any individual one (1) cubic centimeter (cc) of that individuals blood contains the same quantity of alcohol as 2100 cubic centimeters (cc) of the individuals alveolar breath, if both blood and breath are taken at the same time. Breath testing instruments are designed to collect a definite volume of alveolar breath under known conditions of temperature and pressure. This known volume of alveolar breath is analyzed by chemical procedures for the exact quantity of alcohol present, with analysis being done within the instrument. When the quantity of alcohol is determined from a known volume of alveolar breath, a simple calculation(automatically done by the instrument) is made 
to determine the quantity of alcohol present in $2100 \mathrm{cc}$ of that same alveolar breath, which is approximately the quantity of alcohol present in one (1) cc of blood of the individual at the same instant the alveolar breath sample was taken.

These instruments are self-contained units designed to make the alcohol analysis, and to record by meter, the quantity of alcohol in $2100 \mathrm{cc}$ of alveolar breath, recording the reading in percent blood alcohol. (DOH, DDC, 1991, Breath Alcohol-Analysis Program)

There are many advantages when choosing the breath-test. A sample of breath is more easily obtained than any of the other physiological fluids(i.e., urine). The operation of breath-testing instruments is very simple when compared to the procedure(s) used in determination of alcohol in physiological fluids. Also, duplicate samples of breath can be obtained and analyzed with an expenditure of only five minutes additional time. Another advantage to the breath-test is that the sample can be used as a screening test(preliminary to making blood tests), which can be used as evidence with other objective tests to prove drunk driving. And finally, there is no problem of continuity of a sample custody, since the accused person blows directly into the instrument, in the presence of an operator. 


\section{DRUGGED DRIVING MODEL}

The practice of drug analysis has undergone great changes in the last decade, culminating in the present analytical capability to search for, identify and quantify all of the commonly used drugs, and many of their metabolites, in suitably small specimens of biological fluids. The changes of greatest impact on the problems of drugs and traffic safety, apart from the increased interpretative information, have been developments in the "monitoring" of concentrations of therapeutic drugs, advances in emergency analytical toxicology, and the development of immunochemical methods of analysis for many new drug analytes. (Dubowski, 1980) Special constraints apply to drug analysis in connection with traffic safety, as summarized in the following list:

\section{SPECIAL FACTORS IN DRUGS/DRIVING TOXICOLOGY}

1.) Limited access to subject

2.) Limited specimen quantity

3.) Need to fix time vs effect

4.) Lack of information about tolerance/habituation/dependency

5.) Probability of court challenge

For these reasons, it is useful to be aware of the drug analysis of potential interest as well as of recently obtained results in drugs/driving surveys.

A directly related concern is the interpretation of results of the many analyses for drugs now possible, often at very low concentrations and long 
after initial drug intake. Some of these issues in the interpretation of results of drug analysis, especially with respect to drugs-and-driving are given in the following list: (Dubowski, 1980)

SOME INTERPRETATION ISSUES IN DRUGS-AND-DRIVING

1.) Active drug vs Active/Inactive metabolite(s)

2.) Concentration vs Effect Curves

3.) Habituation and Tolerance Phenomena

4.) Dose/Time/Concentration Interrelations

5.) Pharmacodynamics and Pharmacokinetics Aspects

Until a specialized body of information is developed on concentrations of drugs and their metabolites in biological specimens in relation to driving fitness, reliance must be continued upon the relevant literature in pharmacology, clinical toxicology, and therapeutic drug monitoring. Computerized information services (e.g., Medline, Toxline, etc.) make much of this information readily accessible. (Dubowski) 


\section{THE DRUG RECOGNITION EXPERT (DRE)}

The term "DRE" is used to designate an individual who is especially trained to conduct examinations of suspected drug-impaired drivers. Police in today's world are having a difficult time determine if a person is driving under the influence of alcohol or drugs. The DRE training school program will help our law enforcement agencies to fully understand and develop a battery of tests to determine if an individual is under the influence of drugs or alcohol while driving. It is not necessary to be a police officer to be a drug recognition expert.

The drug recognition expert procedure is a systematic, standardized method of examing a suspect to determine:

(1). whether the suspect is impaired, and if so,

(2). whether the impairment relates to drugs or medical condition, and if drugs,

(3). the category or combination of categories of drugs that is the likely cause of the impairment.

The drug recognition expert bases his/her conclusion on the following observations of the suspect. The two most important components of the observation list are performance of psychophysical tests and eye examination.

Observations:

1. Appearance

2. Behavior 
3. Performance of psychophysical tests (i.e., stand on one leg, finger to nose, walk and turn)

4. Eyes (i.e., Horizontal gaze nystagmus, Vertical nystagmus, pupil size estimation)

5. Vital signs (pulse, blood pressure, temperature)

A drug recognition expert never reaches a conclusion based on any one element of the examination, but instead on the totality of the facts that emerge.

The U.S. Department of Transportation DRE manual lists the following twelve components as a guide to obtaining evidence:

1. Breath alcohol test

2. Interview of arresting officer

3. Preliminary examination and first pulse

4. Eye examinations

5. Divided attention tests:

a. Romberg balance

b.Walk and turn

c. One leg stand

d. Finger to nose

6. Vital signs and second pulse

7. Dark room examinations and ingestion examination

8. Check for muscle tone

9. Check for injection sites and third pulse

10. Interrogation, statements, and other observations

11. Opinion of evaluator

12. Toxicological examination 
There are seven broad categories that are covered in this program. Each category produces a different set of effects on the human body. This includes signs and symptoms of drug influence.

The seven categories are:

Category

Central Nervous System Depressant

Central Nervous System Stimulants

Hallucinogens

Phencyclidine (PCP)

Narcotic Analgesics

Inhalants

Cannabis
Examples

Alcohol, Barbiturates

Cocaine

LSD

Various analogs

Heroin, Codeine

Glue, Aerosols

Marijuana

Under this program, the drug recognition expert will cover the seven broad categories of drugs.

Once a suspect is apprehended, the twelve step checklist is done. If a DRE is suspicious of impairment that's not related to alcohol, the expert will refer the major indicators of drug impairment that they have learned about. Once all of the tests are fully and correctly completed, and a suspect is considered positive for drug use, other than alcohol, the individual will be brought to court on charges given at the seen of the incident. The most valuable and notable role of the DRE program is that the drug recognition expert can testify in court against the suspect. 
Based on the data and information gathered in this thesis, I can add my own opinion on DRE. I think in the near future we can have a DRE drive along with law enforcement officials. In this scenario, if a driver is pulled over on suspicion of drunk/drugged driving, a highly trained DRE can be at the scene immediately to perform the battery of tests on the suspect. If this scenario becomes too costly, we can have a DRE on call, and pay that person a per-diem rate to come to the scene of the investigation. Secondly, the law enforcement agencies can set-up field units for drugged driving detection. A field unit can be set-up as a "satellite" detection station, where a suspect can be brought for testing instead of the police station's. The suspect will be tested at length by a DRE, and if the suspect is a candidate for drugged driving, the individual will be brought to the police station to be properly arrested. This procedure will reduce traffic flow at police station's when dealing with multiple arrests and lengthy tests. 
In essence, all drugs which are available are being used to some extent, therefore, I researched the following 7 classes of drugs which show the highest incidence rates in DUID:

1. MARIJUANA

2. TRANQUILIZERS

3. SEDATIVE/HYPNOTICS

4. HALLUCINOGENS

5. STIMULANTS

6. NARCOTICS

7. ANTIHISTAMINES (OVER-THE-COUNTER)

Through major various studies by the National Highway Traffic Safety Administration, a report was prepared reflecting the most current knowledge on the relationship of drug use to highway safety. The review covered key studies for the period 1972 through 1987, with major emphasis placed on current research since 1985. The technical report was divided into four area's of research: 1.) Fatally Injured Drivers; 2.) Injured Drivers; 3.) Drivers Detained by the Police; and 4.) Studies on the effects of Drug use on simulated Driving (laboratory, simulation, and on-the-road studies). The frequency of drug use by fatally injured drivers was found to be 10-15\% with $50-80 \%$ of the drivers also using alcohol. The most common drugs seen in Fatally injured drivers was marijuana, other less frequent drugs included diazepam, barbiturates, methaqualone, cocaine, codeine, phencyclidine and amphetamines. The studies regarding drug use by impaired drivers detained by the police showed an incidence ranging $14-50 \%$. Simulated driving data has shown a variety of drugs to impair skilled performance, 
these drugs include: diazepam, secobarbital, marijuana, antihistamines, antidepressants, anxiolytics and hypnotics. The arrested drivers data reflected specimens tested where the blood alcohol content was less than $0.10 \%$ weight by volume. 
THE SEVEN CLASSES OF DRUGS WHICH SHOW THE HIGHEST INCIDENCE RATES OF DUID: (Based on the Medical Examiner's Data)

CLASS

CANNABIS

TRANQUILIZERS

SEDATIVE / HYPNOTICS

HALLUCINOGENS

STIMULANTS

NARCOTICS

ANTIHISTAMINES (OVER THE

COUNTER)
$\underline{D R U G}$

MARIJUANA

DIAZEPAM

BARBITURATES

PHENCYCLIDINE

COCAINE

CODEINE

DIPHENHYDRAMINE

\section{RECAP OF DATA:}

FATALLY INJURED DRIVERS..........10-15\%

INJURED DRIVERS............................... 22\%

ARRESTED DRIVERS............................14-50\%

This research suggests these drugs are excellent targets for future evaluation as potentially hazardous to highway safety.

The recent NHTSA report concluding that "there is a reasonable basis for setting concentrations for the drugs and fluids" shown in Table 4, is reproduced below: 
TABLE 4:

THRESHOLD DRUG CONCENTRATIONS FOR PRESUMPTIVE
IMPAIRMENT
DRUG IMPAIRMENT CORRELATION PLASMA/BLOOD SALIVA

URINE

\begin{tabular}{|c|c|c|c|c|}
\hline \multirow[b]{2}{*}{ Drug } & \multirow[b]{2}{*}{$\begin{array}{l}\text { Impalrment } \\
\text { Correlation }\end{array}$} & \multicolumn{3}{|c|}{ Concentrations } \\
\hline & & Plasmanblood & Saliva & Urine \\
\hline Marjuana & $\begin{array}{l}\text { Linear } \\
\text { Comrelation }\end{array}$ & $\begin{array}{l}P 2 \mathrm{ng} / \mathrm{ml} \\
\mathrm{B} 1 \mathrm{ng} / \mathrm{ml}\end{array}$ & No & $\begin{array}{c}80-100 \mathrm{ng} / \mathrm{ml} \\
\text { THC-9-201 }\end{array}$ \\
\hline Disicpan & $\begin{array}{c}\text { Time } \\
\text { Course }\end{array}$ & $\begin{array}{c}\text { Plasm2 } \\
150 \mathrm{ng} / \mathrm{ml}^{\prime}\end{array}$ & $2.7 \mathrm{ng} / \mathrm{ml}$ & $\begin{array}{c}\text { None } \\
\text { Deverninod }\end{array}$ \\
\hline Diphenhydramine & $\begin{array}{l}\text { Time } \\
\text { Course }\end{array}$ & $\begin{array}{c}\text { Plasma } \\
65 \text { agtal }\end{array}$ & $180 \mathrm{ng} / \mathrm{m}$ & $\begin{array}{c}\text { None } \\
\text { Deterwained }\end{array}$ \\
\hline Secobarbital & $\begin{array}{l}\text { Time } \\
\text { Course }\end{array}$ & $\begin{array}{c}\text { Plasma } \\
1.67 \mathrm{\mu g} / \mathrm{ml}\end{array}$ & $0.5 \mu \mathrm{g} / \mathrm{ml}$ & $\begin{array}{c}\text { None } \\
\text { Determined }\end{array}$ \\
\hline Methaquatone & $\begin{array}{l}\text { Time } \\
\text { Course }\end{array}$ & $\begin{array}{l}\mathrm{P} \text { and } \mathrm{B} \\
1.5 \mathrm{\mu g} / \mathrm{ml}\end{array}$ & $150 \mathrm{D} 8 \mathrm{fml}$ & $\begin{array}{c}\text { None } \\
\text { Determined }\end{array}$ \\
\hline
\end{tabular}

Armed with these scientific data, the task of establishing statutory impairment levels for DUID in any, or all, jurisdictions remains a very difficult one indeed. While the alcohol model has been accepted by legislatures, the defense bar continues to mount challenges on many fronts, some which are successful. Where to begin is a question which must be addressed early in the process. Attempts to develop an all encompassing statute which identifies serum concentration levels of all drugs with a potential for driver impairment can only fail due to lack of necessary studies to serve as documentation. How shall this process be commenced? 


\section{RHODE ISLAND LAWS REVISED}

In July of 1990, (Appendix B) a new law was made to further the issue(s) of driving under the influence of liquor or drugs. The new revised law now states that section 31-27-2 will be used to charge a person of driving under the influence of liquor, drugs or toluene, or any controlled substance defined in Chapter 28 of title 12, or any combination thereof, will be proof enough for guilt.

This act amended the provisions for driving under the influence by allowing for a conviction by evidence other than chemical analysis, and increasing certain penalties. This act would also allow for suspension by the registry of a license based upon a conviction of an offense involving illegal drugs.

This law will enable the drug enforcement personnel to make convictions in the court of law much easier.

Also in July of 1990, (Appendix C) a subsection was added and passed as law to section 31-27-2. It states in section 31-27-2.4, driving while in the possession of controlled substances, the act will impose a six month suspension on the license of any person who operates any motor vehicle knowingly having in said motor vehicle or in his or her possession a controlled substance.

This act will not apply to a person who lawfully possess a controlled substance as defined in section 21-28-1.02, as a direct result and pursuant to a valid prescription from a licensed medical practitioner, or except as otherwise authorized by chapter $21-28$ of the general laws. 
To have this act pass really generates the public to think twice about driving with illegal narcotics in their possession, either internally or externally. This again will help our enforcement and judicial system in increasing convictions with less difficulty. 


\section{CONCLUSIONS}

One of the objectives of this study was to determine if and to what degree, a drug will effect driving. It is important to reiterate the limitations and underlying assumptions utilized in the present study. Because of lack of adequate epidemiological data that would best characterize the role that drugs may play in traffic crashes or arrests, it was necessary to use measures of impairment based on laboratory tests and medical examiner's data. The calculations and drug concentration thresholds presented here can only serve as preliminary indicators of possible relationships between impairment and drug levels. No data is available on assessing the role that frequent or chronic use of drugs may play, either with respect to the development of tolerance or alterations in drug pharmacokinetics.

Although the results of the data are not always consistent, there are a number of conclusions that can be drawn from this study. The drugs or drug classes most likely to be found in a traffic fatality, injury, or DUID arrest in the State of Rhode Island are: alcohol, cocaine, marijuana, barbiturates, benzodiazepines, narcotic analgesics, and antihistamines.

The two major drugs in the State of Rhode Island which can result in driver impairment are cocaine and marijuana. Legislation can be made for marijuana because of the fact that it's categorized in Schedule I. Given that any concentration of a Schedule I controlled substance in the blood is evidence of the use of a contraband, one proposal would be to include language in the DUID statute following the DUIA model. Identifying a driver who tests positive for marijuana, would result in a guilty plea of violating the statute. 
For the drug cocaine, the enforcement process is a bit more complex. Cocaine is listed as a Schedule II according to the federal criteria set forth in the Comprehensive Drug Abuse Prevention and Control Act of 1970 and the Uniform Controlled Substances Act. Therefore, if an individual is found with any trace of cocaine in their system while driving, to enforce a DUID statute, that individual driving would have to submit a legal prescription written by his/her physician to verify that the individual is using cocaine as an adjunct to therapy. If that person can not provide a prescription, then that person will be prosecuted for possession of an illicit drug. Chronic use of sedative-hypnotics such as long-acting barbiturates (e.g., phenobarbital) can effect the driving performance of the driver. Sedating antidepressants can impair driving at least in the acute phase of therapy, and this effect will be enhanced by the presence of an anxiolytic. The H1-antihistamines also produce sedation which can effect non-tolerant persons. The effects of narcotic analgesics on performance has not been well documented, but studies show that meperidine produces significant impairment, and that codeine combined with alcohol can also affect driving performance.

Many benzodiazepines such as diazepam and lorazepam are impairing at therapeutic dosages, especially when combined with alcohol. While low doses of amphetamine improve reaction time, it must be emphasized that no studies have been conducted with stimulant dosages approaching those used by abusers, which can result in hyperexcitability and hallucinations. Additionally, the extreme fatigue and drowsiness following the use of the drugs would obviously impair driving.

In review, the following recommendations are as follows: It is desirable that forensic toxicology laboratories that test specimens originating from accidents, fatalities, or DUID arrests, should routinely test 
for the above drugs or drug classes. Whenever possible, laboratories should perform routine quantification's for these potentially hazardous drugs in blood specimens submitted for analyses. There is a definite need for more stringent laws for persons driving under the influence of drugs and alcohol. Stiffer penalties are needed for individuals that are driving impaired to let them realize the risk they are taking. Besides license suspension after the first offense, there should be a two part course including a pharmacology section describing the deadly effects of the combination of drugs and alcohol, the second section dealing with driver education rehabilitation--relearning the rules of the road. Upon successful completion of the course, re-admittance will be given to use the roadways.

There is a need to train our law enforcement teams to notice impaired drivers when alcohol is not involved on the roadways. This will include more classroom and roadside instructions to teach the enforcement agencies to identify drivers that are impaired due to drugs, alcohol, or a combination of both. This is where we can utilize the DRE program to its fullest extent. The main objective with the DRE program is to be very similar to the fire/emergency rescue team. Many of today's firemen are also emergency medical technicians (EMT's). These people who are dually trained in their field can be utilized as a fireman or an emergency medical technician when responding to a fire. The DRE program should be designed very similar to that program. A police officer can be trained to become an drug recognition expert. When he/she responds to a drunk/drugged driving call, the officer can use both DRE and police officer skills to properly handle the situation. And finally, there is a definite need for ongoing research in this rapidly changing area. 


\section{REFERENCES}

K.G Stewart, B.M Sweedler, C.C. Hughes. Proceedings of the section on Alcohol, Drugs and Traffic Safety of the 35th International Congress on Alcohol and Drug Dependence. Oslo, Norway, July 1988. National Clearinghouse for alcohol and Drug Information, Rockville, MD. 1988.

Hershal Jick, et al. "Sedating Drugs and Automobile Accidents leading to Hospitalization." American Journal of Public Health. 71 (1981): 1399-1400.

Robert Miller. "Investigation of the effects of Secobarbital on Cognitive and Psychomotor skills related to driving an Automobile." Thesis. p. 1-57. 1981.

American Academy of Forensic Sciences. 1988. Current Status Report Drugs and Driving Committee. 1965.

Traffic Laws Commentary (Editorial): Drugs and Driving. 65-1, 1-17,

G.D. Mellinger, D.I. Manheiner, M. B. Balter. "Psycho-therapeutic drugs: Use among adults in California." California Med. 109(1968): 445-52.

E.J. Woodhouse. "The incidence of drugs in fatally injured drivers." U.S. Department of Transportation. 800(1975):411.

E.G. Zimmermann, et. al. "Measurement of Delta-9tetrahydrocannabinol (THC) in whole blood samples from impaired motorists." Jour. of Sci. 28(4) (1983):957-62.

S. Sharma. "Barbiturates and Driving." Accident analysis and Prevention. 8(1976):27-31. 
J.G. Garriott and N. Latham. "Drug Detection in cases of driving under the influence." Jour. of For. Sci. 21(1976):398-415.

F. Gengo, C. Gabos, J. Miller. "The pharmacodynamics of diphenhydramine-induced drowsiness and changes in mental performance." Clinical Pharmacology Thera. 45(1989): 15-21.

Risto Honkanen, et. al. "Role of Drugs in Traffic Accidents." British Medical Jour. 281(1980):1309-12.

H.H. McCurdy, et. al. "Incidence of Methaqualone in Driving-underthe-Influence (DUI) cases in Georgia." Jour. Anal. Tox. 5(1981):270-4.

A.F. Williams, et. al. "Drugs in Fatally Injured Young Male Drivers." Public Health Reports. 100(1985):19-25.

M. Linnoila and M.J. Mattila. "Interaction of alcohol and Drugs on psychomotor skills as demonstrated by a driving simulator." Brit. Jour. of Pharmacology. 47(1973):671-2.

M. Linnoila and S. Hakkinen. "Effects of diazepam and codeine, alone and in combination of alcohol, on simulated driving." Clin. Pharmacology and Thera. 14(1974):368-73.

W. Neuteboom and P. Zweipfennig. "Driving and the Combined use of alcohol in the Netherlands." For. Sci. Int. 25(1984);185-89.

J. Valentour. "A survey of Drug use among Impaired Drivers in Virginia." Medico-Legal Bulletin(Virginia State Health Dept.), 29(1980):1-7.

G. Cimbura, et. al. "Incidence and Toxicological Aspects of Drugs detected in 484 fatally injured drivers and pedistrians in Ontario." Jour. For. Sci. 27(4) (1982):855-67.

DOH,DDC,1984 Drugged Driving Standards Survey. 
DOH,DDC, 1991 Breath Alcohol-Analysis Program.

K.M. Dubowski. "Analysis of Drugs in biological fluids: state-of-theart. University of Oaklahoma." Alcohol Drugs and Traffic Safety. II (1980): $433-41$.

U.S. Department of Transportation. 1993. Drug Evaluation and Classification Training program.

General Laws of Rhode Island. 1956, as amended, Title 31, Chapter 27 , section 2(a). 


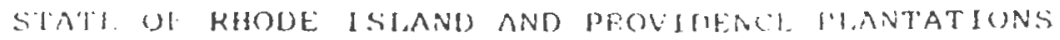
DEMARTMFNT OE HEALTH COMMUNI'TY HEALTH SERVICLS DIVISION QIF IRUG CONTRRII

TITLE 31 . CHAPTER 27

\title{
MOTOF VEHICIE OFEENSES
}

\author{
SECTION . \\ $31-27-2$. \\ $31-27-2.1$ \\ $31-27-2.2$ \\ $31-27-2.3$ \\ $31-27-2.4$ \\ $31-27-2.5$ \\ $31-27-2.7$ \\ $31-27-3$
}

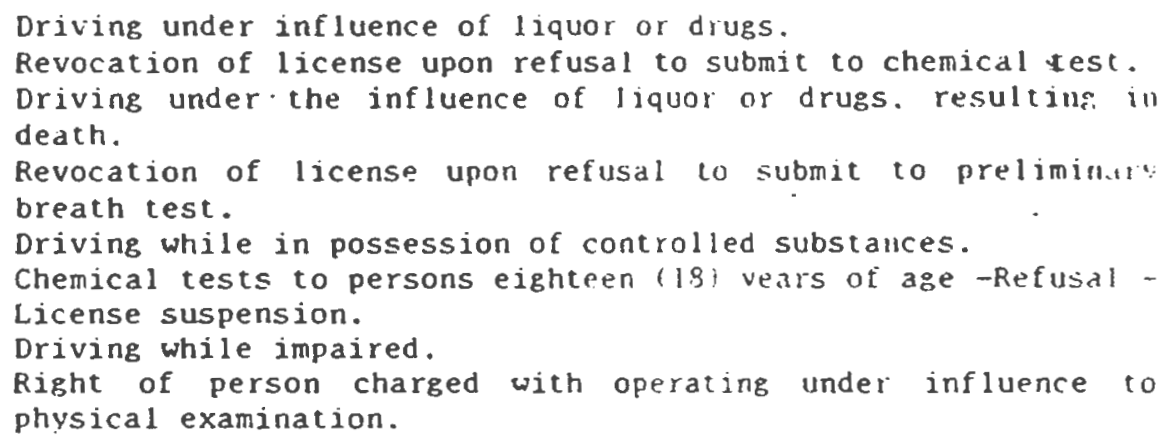

31-27-2. Uriving under influence of liquor or drugs. - 1. Whoever operates or otherwise drives any vehicle in the state while under the intluence of any intoxicating liquor. drugs. toluene or anv controlled substarice as defined in chapter 28 of title 21 , or any combination thereof. shall lie guilty of a misdemeanor and shall be punished as provided in paragraph id! of this section.

(b) (1) Any person charged under subsection la: of this section whose: blood alcohol concentration is one-tenth of one percent (.l\%) or more by weight as shown by a chemical analysis of a blood. breath or urine sartple shall le guilty of violating subsection (a) of this section. Thas provision shall $110 t$ preclude a conviction based on other admissible evidence. Proof if guill unim this section may also be based on evidence that the person charged was under the influence of intoxicating liquor. drugs. toluene, o $i$ anv controlled substance defined in chapter 28 of title 12, or any combination thereof. to a degree which rendered such person incapable of safely operating a vehicle. The fact that anv persoon charged with violating this section is or has been legally entitled t.n use alcohol or a drug shall not constjtute a defense against ariv charse of violating this section.

(2) Whoever operates or otherwise drives all: vehicle in the stato with a blood presence of any scheduled controlled substance as defined within chapter 28 of title 21 , as shown by analysis oi a blood or urine sampie. shall 
be buitu of a misdemeanor and shall be punished as provided in subsertion ld: of this section.

(c) In any ciminal prosecution for a violatio: of paragraph 'al of this section, evidence as to the amount of intoxicating liquor. toluene. or any controlled substance as defined in chapter 28 of title 21 . or any combination thereof in the defendant's blood at the time allezed as shown by a chemical analysis of the defendant's breath. blood or urine of other bodily substance shall be admissible and competent provided that evidence is presented that the following conditions have been complied with.

(1) The defendant has consented to the taking of the test upori which said analysis is made. Evidence that the defendant had refused to submit to said test shall not be admissible unless the deiendant elects to testify.

(2) A true copy of the report of the test result was mailed within seventy-two (72) hours of the taking of said test to the person submitting to a breath test.

(3) Any person submitting to a chemical test of blood. urine $n$ ather body fluids shall have a true copy of the report of the test result mallet to him within thirty ( 30$)$ days following the taking of the test.

(4) the test was performed according to methods and with equip:..nt approved by the director of the department of health of the stale of Rhade Island and by an authorized individual.

(5) Equipment used for the conduct of such tests by means of breath analysis had been tested for accuracy within thirty (30) days preceding the test by personnel qualified as hereinbefore provided, and breathalyzer operators shall be qualified and certified by the department of health within every three hundred sixty-five ( 365 , days of the test.

(6) The person arrested and charged with operating a motor vehicle while under the influence of intoxicating liquor, toluene, or any controlled substance as defined in chapter 28 of title 21. or anv combination thereof in vinlation of paragraph (a) of this section was afforded the opportunity to have an additional chemical test and the officer arresting or so charging such ferson informed such a person of this light and afforded him a reasonable oppoitunits to exercise the same and a notation to this efiect is made in the ufficial records of the case in the police department. Refusal to permit such arditionil chemical test shall render incompetent and inadmissiblp in evidence the orieinal repori.

(d) (1) Every person convicted of a first vinlation shall be sutjject in a fine of not less than one hundred dollars (\$100) nir) more than three hundied dollars (\$300) and shall be required to perform ten 10 ) to sixty (60) hours of public cormunity service and/or shall be imprisuned for up to one il. vear. Said sentence may be served in any unit of the adult correctional institut inn in the dicretion of the sertencing judk". Said peison's diving license shall r." 
suspended 101 a perrod of three (b) nonths 10 six (b) months. The selltencills judge shall require attendance at a special course on driving while intuxicated or under the influence of a controlled substance and:or alcohol or drug treatment for the individual.

(2) Every person convicted of a second violation within a five 15 . year period shall be subject to a mandatory fine of four hundred dollars $1 \$ 4001$. Said person's driving license shall be suspended for a period of one (1) vear 10 two (2) years and said individual shall be sentenced to not less than ten 110 , days nor more thall one (1) year in jail. Said sentence may be served ill an: unit of the adult correctional institution in the discretion of the selltencin: judge; however. not less than forty-eight (43) hours of imprisonment shall be served consecutively. The sentencing judge shall require alcohol or drug treat.ment for the individual.

(3) Every person convicted of a third or subsequent violation within a five (5) year period shall be subject to a mandatory fine of four hundred dollars (\$400). Said person's driving license shall be suspended fo; i period of two (2) vears to three (3) years and said individual shall br sentenced to not less than six (6) months nor more than one (1 i year in jall. Said sentence may be served in any unit of the adult correctional institution in the discretion of the sentencing judge; however, not less than fortv-eight iib. hours of imprisonment shall be served consecutively. The sentencing judge shall require alcohol or drug treatment for the individual.

(4) For purposes of determining the period of license suspension a prior violation shall constitute any charge brought and sustained under the provisions of this section or section $31-27-2.1$. as amended.

(5) Any person convicted of a violation under this section shall pay a highway assessment fine of five hundred dollars i\$500). Said assessinellt shall be imposed upon July 1.1982 and every year thereafter and effective January 1. 1986 shall be deposited in a restricted purpose receipt account separate from all other fines collected by the judicial department and shall be collected from a violator before any other fines authorized by this section. Said assessments shall be used for the purposes of administration. screening. alcoholic and/or drug treatment and enforcerrent based upon the following percentages -- fitty-six percent ( $56 \%)$ of the department of mental heilth. retardation and hospitals. thirty-two percent $(32)$ to the department of transportation. and twelve percent $(12 \%)$ to the department of health.

(6) (a) It the person convicted of violating this sectiogris under the age of eighteen (18) years, for the first violation he or she,shäll bo required to perform ten $(10)$ to sixty (60) hours of public community service. and said juvenile's driving license shall be suspended for a period of six in. months, and may be suspended for a period up to eighteen (18! months. The sentencing judge shall also require attendance at a special course on driving while intoxicated or under the influence of a controlled substance and alcohol or druk education aridor treatment for the juvenile. The juvenile mav also be required to pav a highway assessment fire of no nore than five hundred dnllars 
(\$\$00). and the assessment imposed shall be distributed 10 the percelliages stated in subsection (S) above.

(b) If the person culluicted of violating this sectlon is under the age of eighteen (18; years. for a second or subsequent violation he or she shall be subject to a mandatory suspension of driving license until such time as he/she is twenty-one (21) years of age and may in the discretion of the. sentencing judge also be sentenced to the Rhode Island training school for a period of not more than one (1) year and/or a fine of not more than five hundred dollars $(\$ 500)$.

(7) Any person convicted of a violation under this section may undergo a clinical assessment at a facility approved by the department of MHRH. Should this clinical assessment determine problems of alcohol. drug abuse or psychological problems associated with alcoholic or drus abuse. this pcrson shall be referred to the T.A.S.C. (treatment alternatives to street. crine; program for treatment placement, case management and monitoring.

(e) Percent by weight of alcohol in the blood shall be basted upon milligrams of alcohol per one hundred (100) cubic centimeters of blood.

(f) (1) There is hereby established an alcohol and drug safety unIt within the department of transportation to administer an alcohol safety action program. The program shall provide for placement and follow-up for persons who are required to pay a highway safety assessment. The alcohol and drug safety action program will be administered in conjunction with alcohol and diug programs within the department of mental health, retardation and hospitals. the department of health and department of transportation. The alcohol and drus. safety action program shall be implemented on January 1. 1953.

(2) Persons convicted under the provisions of this chapter shall te required to attend a special course on driving while intoxicated or under the influence of a controlled substance and/or participate in an alcohol or drug treatment program. A copy of any violation under this section shall be forwarded by the court to the alcohol and drug safety unit. In the event that persons convicted under the provisions of this chapter fail to attend and complete the above course or treatment program. as ordered by the judge. then said person may be brought before the court, and alter hearing as to whe the order of the court was not followed, may be sentenced to jail for a periud not exceeding one ( 1 ) vear.

(3) Effective January 1. 1986 there is hereby created within the department of transportation the Alcohol and Drug Safety Action Program Account to be tunded by monies which are derived from highway safety assessments defined in sections $31-2 i-2 i d)(5) .31-27-2(d)(6)(a)$ and $31-27-2.1(a)(5)$ and dedicated for the purpose of funding activities described in section 31-27-24flil:. Annual appropriations shall not exceed the amount of receipts anticipated to be collected in the vear of the appropriation. Expenses shall not excerd appropriations; however. should receipts not be sufficient to support expendicures made 1 in accordance with appropriations. funds shall be made 
available from receipts collected in the subsequent vear. Should recelpts exceed expendlures in any one year. such receipts shall be accumulated within the alcohol and drug safety action prograr account.

(g) The director of the health department of the state of Rhode lsland is empowered to make and file with the secretary of state, regulations which prescribe the techniques and methods of chemical analysis of the person's body fluids or breath. and the qualifications and certification of individuals authorized to administer such testing and analysis.

(h) Jurisdiction for violations of this section is hereby given to the district court for persons eighteen (18) years of age or older and to the farily court for persons under the age of eighteen (18; years and said courts, shall have full authority to impose any sentence authorized and to order the suspension of any license for violations of this section. All trials in the district court and family court of violations of the section shall be scheduled within thirty $(30)$ days of the arraignment date. No continuance or postponement shall be granted except for good cause shown. Such continuances as are necessary shall be granted for the shortest practicable time.

(i) No fines, suspensions, assessments, alcohol or drug treatment programs. course on driving while intoxicated or under the influence of a controlled substance. public community service or jail provided for under this section can be suspended.

(j) An order to attend a special course on driving while intoxicated that shall be administered in cooperation with a college or university accredited by the state shall include a provision to pay a reasonable tuition for such course in an amount not less than twenty-five dollars $(\$ 25.00 !$.

(k) For the purposes of this section, any test of a sample of blood. breath or urine for the presence of alcohol. Which relies in whole or in part upon the principle of infrared light absorption is considered a chewical test.

(1) If any provision of this section or the application thereof shall for any reason be judged invalid, such a judgment shall not affect. impair or invalidate the remainder of the section, but shall be confined in this offect to the provision or application directly involved in the controversy giving rise to the judgment.

31-27-2.1. Refusal to submit to chemical test. - ia) Ary person who operates a motor vehicle within this state shall be deemed to have given his consent. to chemical tests of his breath. blood, andior urine for the purpose of detersining the chemical content of his body fluids or breath provided that no more than two complete tests. one for the presence of intoxicating liquor and one for the presence of toluene or any controlled substance as defined in section 21-28-1.02i6) of the General Laws. shall be administered at the darection of a law enforcenient of icer having reasonable grounds to belipve surh 
person to have been driving a motor vehicle within this state while under the influence of intoxicating liquor, tolvene, or any controlled substance as defined in chapter 28 of title 21 or any combination thereof. The director of the department of health is empowered to make and ile with the secretarv of stace. regulations which prescribe the techniques and methods of chemical analysis of the person's body fluids or breath and the qualifications and certification of individuals authorized to administer such testing and analysis.

If a person. for religious or medical reasons cannot be subjected to blood tests. he may file an affidavit with the registry stating the reasons why he cannot be required to take blood tests, and a notation to this effect shall be made on his license. If such a person is asked to submit to chemical itests as provided herein. he shall only be required to submit to chemical tests of his breath or urine. When a person is requested to submit to blood tests, only a physician or registered nurse or a medical technician certifjed under regulations promulgated by the director of the department of health may withdraw blood for the purpose of determining the alcoholic content therein. This limitation shall not apply to the taking of breath or urine specimers. The person tested shall be permitted to have a physician of his own choosing and at this own expense administer chemical tests of his breath, blood and/or urine in addition to the tests administered at the direction of a law enforcement officer. If such person having been placed under arrest refuses upon the request of a law enforcement officer to submit to the tests as provided in secrion 31-27-2, as amended, none shall be given, but an administrative judge of the division of administrative adjudication. upon receipt of a report oi a las: elliorcement officer that he had reasonable grounds to believe the arrested person had been driving a motor vehicle within this state under the influence of intoxicating liquor, toluene, or any controlled substance as defined in chapter $2 s$ of title 2l, or any combination thereof. that the person had been informed of his rights in accordance with section 31-27-3, that the person had been informed of the penalties incurred as a result of noncompliance with this section. and that the person had refused to submit to the tests upon the request oi a law enforcement officer. shall promptly order that the person's operator's license or privilege to operate a motor vehicle in this state be immediately suspended and that the person's license be surrendered within five (5) days of notice of suspension. An administrative judge pursuant to the terms of subsection ib! within shall thereafter order as follows:

(1) Impose for the first violation a ine in the amount of two hundred dollars $(\$ 200)$ to five hundred dollars $(\$ 500)$ and shall order the person to perform ten $(10)$ to sixty (60) hours of public comunity service. Said person's driving license in this state shall be suspended for a period of three (3) months to six (6) months. The administrative judge shall require attendance at a special course on driving while intoxicated or under. the influence of a controlled substance and/or alcohol or drus treatment for the individual.

(2) Impose for a second violation within a five (5) year perıod a inne in the amount of three hundred dollars is300: to five hundred dollars ¿S500, and said person's driving license in this state shall be suspended foi a 
period of one (1) year to two (2) years. The adinins iative judge shall requjre alcohol and/or drug treatment for the individual.

(3) Impose for third or subsequent violatzon within a five 15! vear period a fine of four hundred dollars (\$400) to five hundred dollars ( $\$ 500 i$ and said person's operator's license in this state shall be suspended for a period of two (2) years to three (3) years. The administrative judge shall require alcohol or drug treatment for the individual. Provided, however, that prior to the reinstatement of a license to a person charged with a third or subsequent violation within a three-year period, a hearing shall be held beiore an administrative judge. At said hearing the administrative judge shall review the persou's driving record, his employment history. fanily background and ally other pertinent factors that would indicate that the person has demonstrated behavior which warrants the reinstatement of his license.

(4) For purposes of determining the period of license suspension a prior violation shall constitute any charge brought and sustained lindei the orovisions of this section of section 31-27-2, as amended.

(5) In addition to any other fines, a highway safety assessinent of iive hundred dollars $(\$ 500)$ shall be paid by any person found in violation of this section. Said assessment shall be deposited in a restricted puipost receipt account separate from all other fines collected by the Division of Administrative Adjudication. Department of Transportation and shall be collected from a violator before any other fines authorized by this section. Said assessment shall be used for the purpose of administration. screening, alcohol and/or drug treatment and enforcement in accordance with section 31-27-2.

(6) No fines, suspensions, assessments, alcohol or drug treatment programs. course on driving while intoxicated or under the influence of a controlled substance. or public community service provided for unitei this section, can be suspended.

(b) Upon suspending or refusing to issue a license or permit as provided in subsection (a) of this section, the division for administrative adjudication shall imediately notify the person involved in writing. and upon his request within fifteen (15) days shall afford him an opportunity for a hearing as early as practical upon receipt of such request in writing. Upon such hearins the administrative judge may administer oaths and mav issue subpoenas for the attendance of witnesses and the production of relevant books and papers. If the administrative judge finds after such hearing that the law enforcenent offices making the sworn report had reasonable grounds to believe-that the arrested person had been driving a motor vehicle within this state while under the influence of intoxicating liquor. toluene, or ani controlled substance as defined in chapter 28 of title 21. or any combination thereof, and that said person while under arrest refused to submit to the tesis upon the request of a Iut enforcement officer. that the person had been informed of his rights ill accordance with section $31-27-3$. and that the person had been intormed of the penaltzes incurred as $a$ result of noncompliance with this section. the administrative judge strall sustain the violation. The administrative judst 
shall then impose the penalties set forth in subsection (a), above. Such action by the administrative judge must be taken within seven ( 7 ) days after such hearing. or $2 t$ shall be presumed that the administrative judze has retused to issue his order or suspension.

(c) For the purposes of this section, any test of a sample of blood. breath or urine for the presence of alcohol which relieves in whole or in part upon the principle of infrared light absorption is considered a chemical test.

(d) If any provision of this section or the applacation thereof shall for any reason be judged invalid, such a judgment shall not affect. impair or invalidate the remainder of the section. but shall be confined in this effect to the provisions or application directly involved in the controversy giving rise to the judgment.

There is hereby appropriated to the Department of Mental Health. Retardation and Hospitals for the period January 1. 1956 through June 30. 195is the sum of two hundred thousand dollars (\$200.000) for the purposes specified in sections $31-27-2(d)(5), 31-27-2(6)(a), 31-27-2(f)(1)$ and $31-27-2.1(5)$, and the state controller is authorized and directed to draw his orders upon the senral treasurer for the payment of said sum or so much thereof as may be from tine to time required upon receipt by him of properly authenticated vouchers sioned bv the director of transportation.

31-27-2.2 Driving under the influence of liguor or drugs. resulting in death. - (a) When the death of any person other than the operator ensues as a proximate result of any injury received by the operation of any vehicle, the operator of which is under the influence of any intoxicatins liquor, toluene. or any controlled substance as defined in chapter 25 nf title 21 or any combination thereof. the person so operating such vehicle shall be guilty of "driving under the influence of liquor or drugs. resulting ill death."

(b) Anv person charged with the comnission of the of iense set forth in subsection (a) shall, upon conviction, be punished as follows:

(1) Every person convicted of a first violation shall be puisshed by imprisonment in the state prison for not less than six 101 s.onths and for not more than ten $(10)$ years, in any unit of the adult correctional institution in the discretion of the sentencing judge. by a fire of not less than five hundred dollars (\$500) nor more than one thousand dollars (\$1.000) and his license to operate a motor vehicle shall be revoked for 3 period oi three $3 i$ yeals. The license privilege shall not thereafter be reinstated until evidence satisfactory to the registrar of motor vehicles establishes that no grounds exist which would authorize the reiusal to issue a license and until the person aives proof of financial responsibility pursuant to chapter 32 of title 31 of the general laws.

(2) Everv person convicted of a second or subsequent rolation whin 3 ijue 15 , vear period shall be pumshed by tnocisonrent in the state 
prison for not less than five (5)years and for not more than twenty (20) vears. in any unit of the adult correctional instztution in the discretion of the sentencing judge, by a fine of not less than elght hundred dollars is\$o0! nor more chan five thousand dollars $(\$ 5,000)$ and his license to operate a motor vehicle shall be revoked for a period of five ubl yedrs. The license privilese shall not thereafter be reinstated until evidence satisfactory to the registrar of motor vehicles establishes that no erounds exist which would authorize the refusal to issue a license and until the person gives proof of financial responsibility pursuant to chapter 32 of title 31 of the general laws.

31-27-2.3 Revocation of license upon refusal to submit to preliminary breath test. - (a) When a law enforcement officer has reason lo -believe that a person is driving or in actual physical control of any rotor vehicle in this state while under the influence of alcohol. the law enforcenent officer may require such person to submit to a prelijinary breath analysis for the purpose of determining such person's blood alcohol content. Such bieath analysis must be administered immediately upon the law enforcement officer's iormulation of a reasonable belief that the person is driving or in actual control of a motor vehicle while under the influence of alcohol. or imriediatel! upon the stop of such person, whichever is later in time. Anv chemical breath analysis required under this section must be administered with a device and in $a$ manner approved by the director of the department of health for that purpose. The result of a preliminary chemical breath analysis ruay be used for the purpose of guiding the offacer in deciding whether an arrest should be made. When a driver is arrested tollowing a preliminary breath analysis, tests may be taker. pursuant to section $31-27-2.1$ of the general laws. The results of a prelininary breath test may not be used as evjdence in anv administrative or court proceeding involving driving while intoxicated or refusing to take a breathalyzer test, except as evidence of probable cause in making the initial arrest.

(b) If a person refuses, upon a lawful request of a law enfurcement officer. to submit to a test under paragraph (a) hereof, that person shall be guilty of an infraction and shall be subject to this penalty provided in section 31-41-4 of the general laws. However, it shall be a defense to a charge of refusine a validly requested preliminary breath analusis that the medical condition of a person precluded the giving of such test.

$31-27-2.4$ Driving while in possession of controlled substances. - In addition to any other penalty prescribed by law. whrever operates any motor vehicle. while knowingly having in said motor vehicle $o_{i}$ in his ol her possession. a controlled substance as defilied in section 21-25-1.02. shall have his or her license suspended for a period of six (b) months.

This section shall not apply to any person who lawfully possesses. controlled substance as defined in section 21-2b-1.02. as a difuct resull and 
pursuant to a valid prescription from a licensed medical practitioner. or except as otherwise authorized by chapter 21-28 of the general laws.

31-27-2.5. Chemical tests to persons eighteen (18) years of age - Refusal - License suspension. - (a) Any person under eighteen ( 18 ) years of age who shall refuse to submit to a chemical test as provided ill section 31-27-2 shall have imposed all the penalties provided by section 31-27-2.1. but shall have his license suspended on a iirst violation for six $(6)$ months. subject to the terms of subsection (e) below;

(b) Jurisdiction for violations of this section is hereby given to the family court.

(c) If such person as set forth in subsection (a) above refuses. upon the request of a law enforcement of ficer, to submit to a test as provided in seiction 31-27-2.1, as amended, none shall be given, but a judge of the family court. upon receipt of a report or testimony of a law enforcement of icer that the had probable cause to stop the arrested person and reasonable grounds to believe the arrested person had been driving a notor vehicle within this state while impaired by intoxicating liquor, toluene. or any controlled substance as defined in chapter 28 of title 21 . or any combination thereof, that the person had been informed of his rights in accordance with section 31-27-3. that the person had been informed of the penalties to be incurred as a result of noncompliance with this section and that the person had refused to submit to the test upon the request of a law enforcement officer. shall promptly order a hearing on whether the person's operator's license or privilege to operate a motor vehicle in this state shall be suspended and upon suspension shall order the license of said person to be surrendered to the Rhode Island department of transportation. division of motor vehicles within three (3) days.

If such person takes a test as provided in section $31-27-2$ and said test determines said person's blood alcohol concentration to be at least four-hundredths of one percent $(.04 \%)$ but less than one-tenth of one percent (.1\%) by weight, said person shall be determined to have been driving while impaired. A judge of the family court shall. pursuant to the terms of subsection (e) within. thereafter order as follows:

(1) A highway safety assessment of one hundred iffty dollars is 150 , or community service in - lieu of highway safety assesstient shall be paid by any person found in violation of this section. Said assessment shall be deposited in a restricted réceipt account separate from all other monies collected by the family court. Said assessment shall be used for the purpose of administialive screening and/or alcohol and drug treatment and enforcement in accordance with section $31-27-2$.

(2) Said person's drivine license shall be suspended for $5 i x: 6$. mouths on a furst violation, and may be suspended for a period of up to wivith (12) monchs. provided said person also shall attend a special court on drivili: 
while intoxicated and provided that sald person shall also actend an alcohol and/or drug treatment program if ordered by the family court judge. Failure o: refusal of said person to attend said course and/or alcohol or drug treatment program shall result in said person's driving license being suspended unti! such, time 3 s the course or treatment program has been completed.

(3) On a second violation of this section. said person's drivins license shall be suspended until such time as he/she is twenty one 12l) vears of age. The sentencing judge shall require alcohol and/or drug treatment ior the individual.

(4) On a third or subsequent violation. said person's driving licerise shall be suspended for an additional period of two (2) years and the sentencing judge shall require alcohol and/or drug treatment for the indiridual.

(5) No suspensions, assessments, driving while intoxicated school or alcohol and/or drug treatment programs under this section can be suspended. shortened, altered. or changed.

(e) Upon suspending a license or permit as provided in subsection (a). (c). or (e) of this section, the family court shall immediately notify the person involved, in writing, as well as the custodial parent if said person is under the age of eighteen (18) years.

(f) The police department which charges any person under elghteen (18) years of age with refusal to submit to a chemical test. driving while impaired by intoxicating liquors or drugs, or driving while under the influence of liquo: or drugs. shall ascertain the name and address of the custodial parent of sajd person and shall notify sajd parent ill wrttine within ten 101 days of the charge.

(g) The Rhode Island department of transportation. division of motor rehicles, upon issuing a first license to a person sixteen (16) or seventeen (17) years of age. Shall provide a writcen notice of the penalties provided by this section. Any violation of this section shall not be considered a criminal otiense.

31-27-2.7. Driving while impaired. - A person under the age of twenty-one $(21)$ but at least eighteen 113$)$ vears of age who takes a test as provided for in section 31-27-2, at the reyuest of a law enforcement officer who believes said person to be driving under the intluence of liquor. shall be detejmined to have been driving while impaired if-the test determines said person's blood alcohol concentration to be at feast four-hundredths of nive percent $(.04 \%$; but less than one-tenth oi one-percent $1.1 \%$ l bv weight.

Should after a hearing in district court it be determaned that

(1) the results of the test are admissible in that it meets all of the conditions as set folth in section $31-2 i-2$ and 
(2) the person has been afforded his/her rights as set forth in section 31-27-2 then the judge shall thereafter order as follows.

(a) A tine of not more than one hundred dollars $(\$ 100)$ and a highway safety assessment of one hundred fifty dollars (SIS0) and thirty (30) hours of community service. Said assessment shall be deposited in the restricted receipt account authorized by section $31-2 i-2$.

(b) Said person's driving license shall be suspended for not less than one (1) nor more than three (3) months on a first violation, provided said person also shall attend a special course in driving while intoxicated and provided that said person shall also attend an alcohol and/or drug treatment program if ordered by the district court judge. Failure or refusal of said person to attend said course and/or alcohol or drug treatment program shall result in said person's driving license being suspended until such tinje as the course in treatment program has been completed.

(c) On a second and subsequent violation of the section said person shall be fined not more than two hundred and fifty dollars ( $\$ 250)$ together with a highway safety assessment of three hundred dollars (\$300) and shall be required to perform up to sixty (60) hours of commity service. Said person's driving license shall also be suspended for not less than three (3) months nor more than six (6) months. The sentencing judge shall also requixe said person to attend a special course in driving while intoxicated and also attend an alcohol and/or drug treatment program.

No suspensions, assessments, driving while intoxicated school or alcohol and/or drug treatment programs under this section can be suspended. shortened, altered or changed.

offense.

Any violation of the section shall not be considered a criminal

31-27-3. Right of person charged with operating under influence to physical examination. - A person arrested and charged with operating a motor vehicle while under the influence of narcotic drugs or intoxicating liquor. whatever its alcoholic content. shall have the right to be examined at his own expense immediately after his arrest, by a physician selected by him. and the officer so arresting or so charging such person shall immediately inform such person of this right and afford him a reasonable opportunity to exercise the same, and at the trial of such person the prosecution must prove that he was so informed and was afforded such opportunity. 


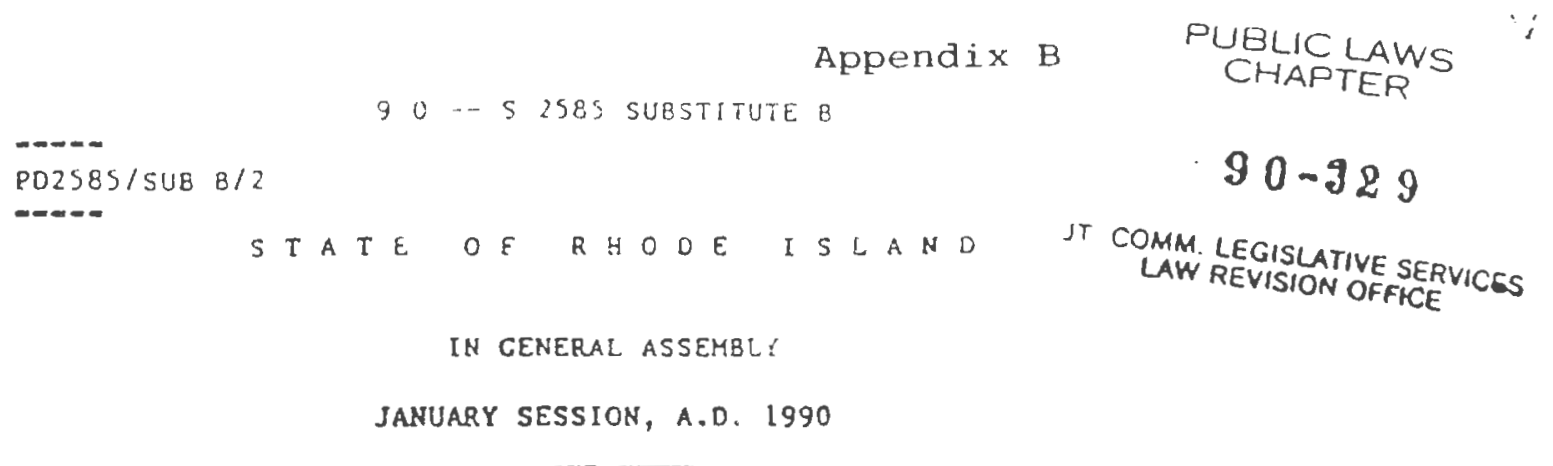

\title{
A N A C T
}

RELATING TO ORIVINC UNOER THE INFLUENCE

OE LIQUOR OR DRUCS

\author{
Introduced By: Senators Hanson, Coldberg, Wiesner and BLais \\ Date Introduced: February 14, 1990 \\ Referred To: Comittee on Sudiciary
}

It is enacted by the Ceneral Assembly as follows:

SECIION 1. Sections 31-27-2 and 31-27-2.1 of the Ceneral Laus in Chapter 31-27 entitled "Motor Vehicle Offenses" are hereby amended to read as follows:

31-27-2. Driving under influence of lique = 25 drugs. - (a) $\star \star \star$

(b) (1) Any person charged under subsection (a) of chis section whose blood alcohol concentracion is one-cench of one percent (.12) or more by veight as shown by a chemical analysis of a blood, breath or urine sample shell be guilty of violating subsection (a) of this section. This provision shall not preclude a conviction based on ocher adraissible evidence. Proof of guilt under chis section may also be based on evidence that the person chsrged was under the influence of intoxicating liguor, drugs, tolvene, or any controlled substance defined in chapter 28 of title 12, or any combinacion thereof, co a degree which rendered such pergon incapable of safely operating a vehicle. The fact that any pergon charged with violacing this section is or has been legally enticled to use alcohol or a drug shall not 
conscicute a defense against any charge of violarag chis secilon.

(2) Whoever operaces or otherwige drives any vehicle in the stace wich a blood presence of any scheduled controlled substance as defined wichin chapter 28 of ticle 21 , as shom by analysis of a blood or urine sample, shall be guilty of a misdemeanor and shall be punished as provided in subsection (d) of this section.

\section{(c) $\star \star \star \star$}

(d) (1) Every person convicted of a Eirst violation shall be subject to a minimam fine of not lesg than one hundred ( $\$ 100)$ dollars nor more than three hundred dollarg $(\$ 300)$ and shall be required to perform ten (10) to sixty (60) hours of public communicy service and/or shall be imprisoned for up to one (1) year. Said sentence may be served in any unit of che adult. correctional insticution in the discretion of the sentencing judge. Said person's driving license shall be suspended for a period of three (3) months to six (6) monchs. The sentencing judge shall require atcendance at a special course on driving while intoxicated or under the influence of a controlled substance and/or alcohol or drug treatment for the individual.

(2) Every person convicted of a second violation within a five (5) year period shall be subject to a mandatory tine of four hundred $(\$ 400)$ dollars. Said person's driving license shall be suspended for a period of one ( 1 ) year to two (2) years and said individual shall be sentenced to not less than cen (10) days nor more than one (1) year in jail. Said sentence may be served in any unit of the adult correccional insticution in the discretion of the sentencing judge; however, not less than forty-eight (48) hourg of imprisonment shall be served consecutively. The sencencing judge shall require alcoholic or drug treatment for the individual. $=-\cdots$

(3) (a) Every persoñ convicted of a third or subsequent violation within five (S) year period shall be subject to a mandatory fine of four hundred ( $\$ 400)$ dollars. Said person's driving license shall be suspended for a period of two (2) years to three (3) years and said individual shall be sentenced to not less than six (6) months nor more 
chan one (1) yoar in jal. Said sencence may be served in any unit of che adult correcional insticution in the discretion of che sencencing judge; however, not less than forty-eight ( 48 ) hours of imprisonment shall be served consecucively. The sencencing judge shall require leohol or drug treatment for the individual.

(b) In addition to the foregoing penaltits, every person convicted of a fourch or subsequent violation wichin five (S) year period shall be subject, in the discretion of the sentencing judge, to having the vehicle owned and operated by suct violator seized and sold by the state of ahode Island, with all funds obtained thereby to be transferred to the general fund.

(4) For purposes of determining the period of license suspension * prior violation shall consticute any charge brought and sustained under the provisions of this section or section 31-27-2.1, as amended.

(S) Any person convicted of a violation under chis section shall pay a highway assessment fine of two-hundred-and-fiftr-dotzars-- $4 \$ z 5 \theta \rightarrow$ Eive hundred dollars (\$500). Said assessment ghall be imposed upon July 1,1982 and every year thereafter and effective January 1,1986 shall be deposiced in a regtricted purpose receipt account separace Erom all other fines collected by the judicial iapartment and shall be collected from a violacor before any ocher fines auchorized by chis section. Said assessments shall be used for the purposes of administration, screening. alcoholic and/or drug treatment and enforcements based upon the following percentages -- fifty-six pe=cenc (56Z) of the department of mencal health, retardacion and hosoicals, thircy-two percent (327) to the department of transporcation, and twelve percent (12z) to the department of health.

(6) fat If the person convicted of violating this section is under the age of eighteen (18) years, for the first violation he or she shall be required to perform ten (10) to sixty (60) hours of public communty service, and said juvenile's driving license shall be suspended for a period of six (6) months. The sencencing judge shall algo require atcendance ar apecial courge on driving while incoxi- 


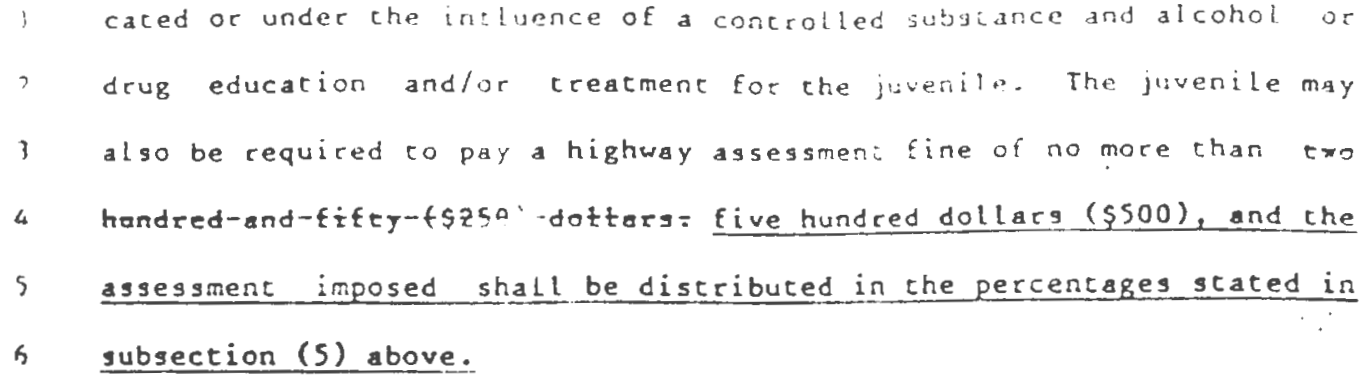
sentencing judge also be sentenced to the thode Island craining school fur a period of not mure than one (1) year and/or a fine of not more than five hundred $(\$ 500)$ dollars.

(7) Any person convicted of a violation under chis section may undergo a clinical assessment at a facilicy approved by the department of MHRH. Should this clinical assesment determine problems of alcohol, drug abuse or psychological problems associaced with alcoholic or drug abuse, this person shall be referred to the T.A.S.C. (creacment alternatives to street crime) program for treatment placenent, case management and monitoring.

(e) * * *

(E)(1) There is hereby established an alcohol and drug safecy unit within the department of transportation to administer an alcohol-safety action program. The program shall provide for placement and follow-up for persons who are required to pay the highway safety assegsment. The alcohol and drug safety action program will be administered in conjunction with alcohol and drug programs uithin the department of mental health, retardation and hospitals, department of health and department of transportation. The alcohol and drug safety action program shall be implemented on January $1,1983$.

(2) Persons convicted under the provigions of this chapter shall be required to attend a secial course on driving while intoxicated or under the influence of a controlled substance and/or participate in an 
alcohol or drug treanenc program. A copy ot any violation under chis section shall be forwarded by the court to the alcohol and drug safecy unit. In the event thar persons convicted ander the provisions of chis chapter fail to actend and complece the above course or treacment program, as ordered by the judge, then said person may be brought before the courc, and after hearing as co why the order of the courc uag not followed, may be sentenced to jail for a period not exceeding one (1) year.

(3) Effective Janusty 1, 1986 there is hereby created within the department of transportation the alcohol and drug safety action program account to be funded by monies which are derived from highway safety assessmencs defined in sections $31-27-2(d)(5), 31-27-2(d)(6)(a)$ and $31-27-2,1(a)(S)$ and dedicated for the purpose of funding activities described in section $31-27-2(f)(1)$. Annual appropriacions shall not exceed the amount of receipts anticipated to be collected in the year of appropriation. Expenses shall not exceed appropriations; however, should receipts not be sufficient to support expendicures made in accordance with appropriations, funds shall be made available from receipts collected in the subsequent year. Should receipts exceed expenditures in any one (1) year, such receipts shall be deposited-in the-stateds-generat-fand accumulated within the alcohol and drug safety action program account.

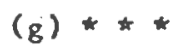

31-27-2.1. Refusal to submit to chemical test. - (a) Any person who operates a motor vehicle within this state shall be deemed to have given his consent, to chemical cests of his breach, blood, and/or urine for the purpose of determining the chemical content of his body fluids or breath provided that no more than two (2) complece tegts, one for the presence of intoxicating liquor and one for the presence of coluene or any controlled substance as defined in section 21-28-1.02(6), shall be administered at the direction of a law enforcement officer having reasonable grounds to believe such person to have been driving ator vehicle within this state while under the 
intivence of intoxicacing liquor. toluene, or any concrolled substance

as defiren in chapcer 28 of ticle 21 or any combination thercof. The

3 dicector of the department of health is empowercd co make and file

4 with the secrecacy of stace, cegulacions which prescribe che tech-

5 niques and mechods of chemical analysig of the pergon's body tiluids or

6 beesch and the qualifications and certification of individuals author-

7 ized to adminiscer such cescing and analysis.

If a person, for celigious or medical reasons cannot be subjected

to blood tests, he may file an affidavit vith the registry stacing the

reasong shy he cannot be required to cake blood cests, and a notation to this effect shall be made on his license. If such a person is agked to submic to chemical cegts as provided herein, he shall only be required to submit to chemical tests of his breach or urine. When a person is requested to submit to blood tests, only a physician or registered nurse or a medical cechnician certified under regulations promulgated by the director of the department of health may withdraw blood for the purpose of determining the alcoholic content therein. This limitation shall not apply to the taking of breath or urine his own choosing and at his own expense administer chemical tests of specimens. The pergon tested shall he permicted in have a physician of his breach, blood and/or urine in addition to the tests administered at the direction of a law enforcement officer. If such pergon having been placed under arrest refuses upon the request of a law enforcement officer to submit to the cests as provided in section $31-27-2$, as amended, none shall be given, but an administrative judge of the division of administrative adjudication, upon receipt of a report of law enforcement officer that he had reasonable grounds to believe the arrested person had been driving mocor vehicle wichin this scate under the influence of intoxicating liquor, toluene, or any controlled substance as defined in chapter 28 of title 21 , or any combination thereof, that the pergon had been informed of his rights in accordsnce with section $31-27-3$, that the person had been informed of the penalties incurred a a result of noncomplisnce wich this section, and 
chat the person had retused to submic to the cegts upon che request of a Law enforcement officfer, shall prompty ordex chac che person's operacor's license or privilege co operace a motor vehicle in this state be imnediately suspended and that the person's license be surcendered within five (S) dayg of nocice of suspension. An administrative judge pursuant to che cerms of subsection (b) within shal! thereafter order as follows:

(i) Impose for the first violation a fine in the amounc of two hundred dollars $(\$ 200)$ to five hundred dollars ( $\$ 500)$ and shall order the person to perform ten (10) to sixty (60) hours of public community service. Said person's driving license in this stace shall be sus* pended for a period of three (3) months to six (6) months. The administrative judge shall require atcendance ac a special course on driving while intoxicated or under the influence of a controlled substance and/or alcohol or drug treatment for the individual.

(2) Impose for a second violation within a five (5) year period a fine in the amount of three hundred dollars ( $\$ 300)$ co five hundred dollars ( $\$ 500$ ) and said person's driving license in chis scate shall be suspended for a period of one (1) year to two (2) years. The administrative judge shall require alcohol and/or drug treacment for the individual.

(3) Impose for a third or subsequenc violacion within a five (5) year period a fine of four hundred dollars ( $\$ 400)$ to five hundred dollars ( $\$ 500$ ) and said person's operator's license in this state shall be suspended for a period of two (2) years to three (3) years. The administrative judge shall require alcohol or drug treatment Eor the individual. Provided, however, that prior to the reinstatement of a license to a person charged with a third or subsequent violation within s three-year period, a hearing shall be held before an adriniscracive judge. AC said hearing the administrative judge shall reviev the person's driving record, his employment history, Eamily background and any other pertinent factors that would indicate that che person has demonstrated behavior which warrantg the reinstatement of his li- 


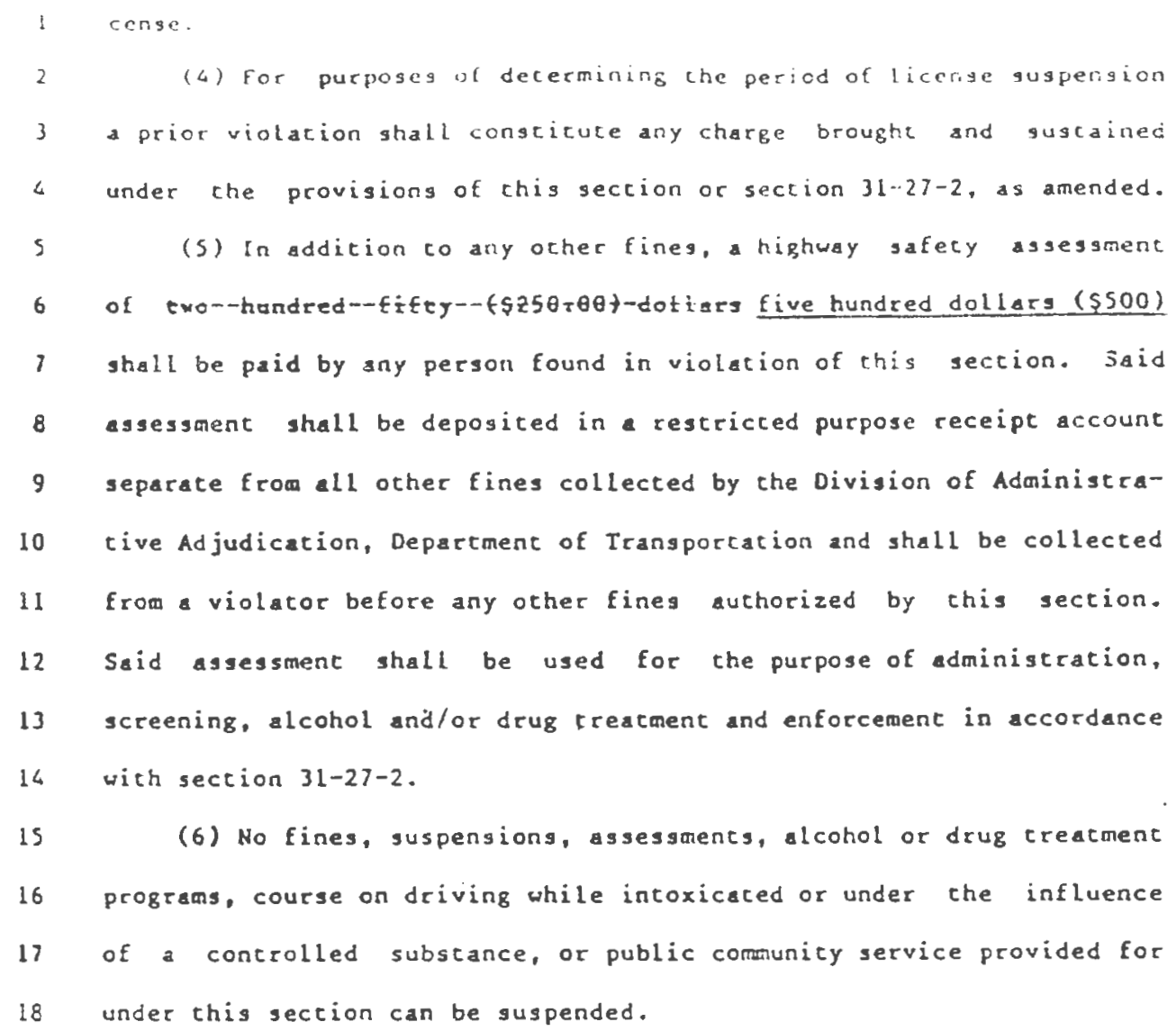

(5) In addition co any ocher fines, a highway safecy asessment

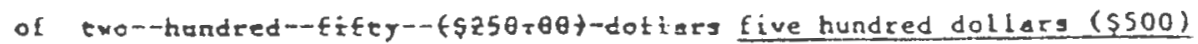
shall be paid by any person found in violation of this section. said assessment shall be deposited in a restricted purpose receipt account separate from all other fines collected by the Division of Administrative Adjudication, Department of Trangporcation and shall be collected from s violator before any other fines authorized by this section. Said assessment shall be used for the purpose of administration, screening, alcohol and/or drug treatment and enforcement in accordance with section $31-27-2$.

(6) No Eines, suspensions, assessments, alcohol or drug treatment programs, course on driving while intoxicaced or under the influence of a controlled substance, or public comunity service provided for under this section can be suspended.

(b) \pm +

SECTION 2. CHAPTER 31-27 OE THE GENERAL LANS ENTITLED "MOTOR VEHICLE OFEENSES" IS HEREBY AMENDED BY ADDINC THERETO THE FOLLOWINC SECIION:

31-27-2.7. Driving while impaired. - A person under the age of tventy-one (21) but ac least eighteen (18) years of age who takes a cest as provided for in section $31-27-2$, at the request of a las enforcement officer who believes said person to be driving under the influence of liquor, shall be decermined to bove been driving while impared if the test determines said person's blood alcohol concentration to be at least four-hundredths of one percent (.04z) but less than one-tenth of one percent $(.1 x)$ by veight. should after hearing in district court it be determined that (1) the results of the cest are admissable in that it meecs all of the condicions set forct in section $31-27-2$ and (2) che person has been 


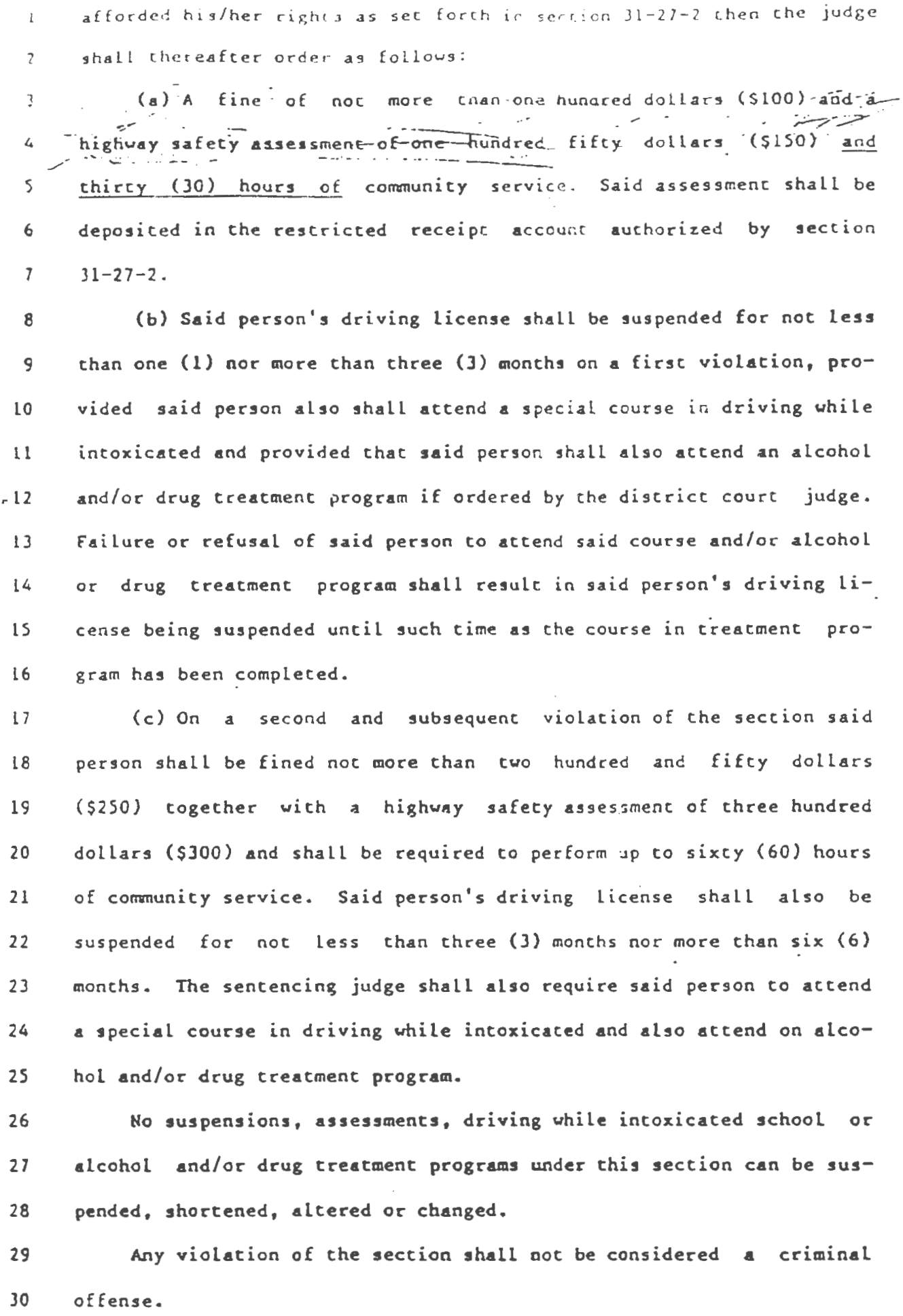

(b) Said person's driving license shall be suspended for not less than one (1) nor more than three (3) months on a first violation, provided said person also shall accend a special course in driving while intoxicated and provided that said person shall also actend an alcohol andlor drug treatment program if ordered by the district court judge. Eailure or refusal of said person to atcend said course and/or alcohol or drug treatment program shall result in said person's driving 1 icense being auspended until such time as the course in treatment program has been completed.

(c) On a second and subsequent violation of the section said person shall be fined not more than tuo hundred and fifty dollars (\$250) together with a highwny safety assesment of three hundred dollars $(\$ 300)$ and shall be required to perform ap to sixty (60) hours of communicy service. Said person's driving license shall also be suspended for not less than three (3) monchs nor more than six (6) monchs. The sencencing judge shall also require said person to actend apecial course in driving wile incoxicated and also actend on alcohol and/or drug treatment program.

No suspensions, assessments, driving while intoxicated school or alcohol and/or drug treatment programs under this section can be suspended. shortened, altered or changed. Any violation of the section shall oot be considered a criminal oEfense. 
SECTION 3. This ace shall take effect upon passage.

$-\infty-\infty-$

POL505/5U8 B/2

-añ 
EXPLANATIOH:

BY THE LECISLATIVE TOUNGI:.

of

AN ACT

RELATING TO ORIVING UNDER THE INFLUENCE

OF LIQUOR OR DRUGS

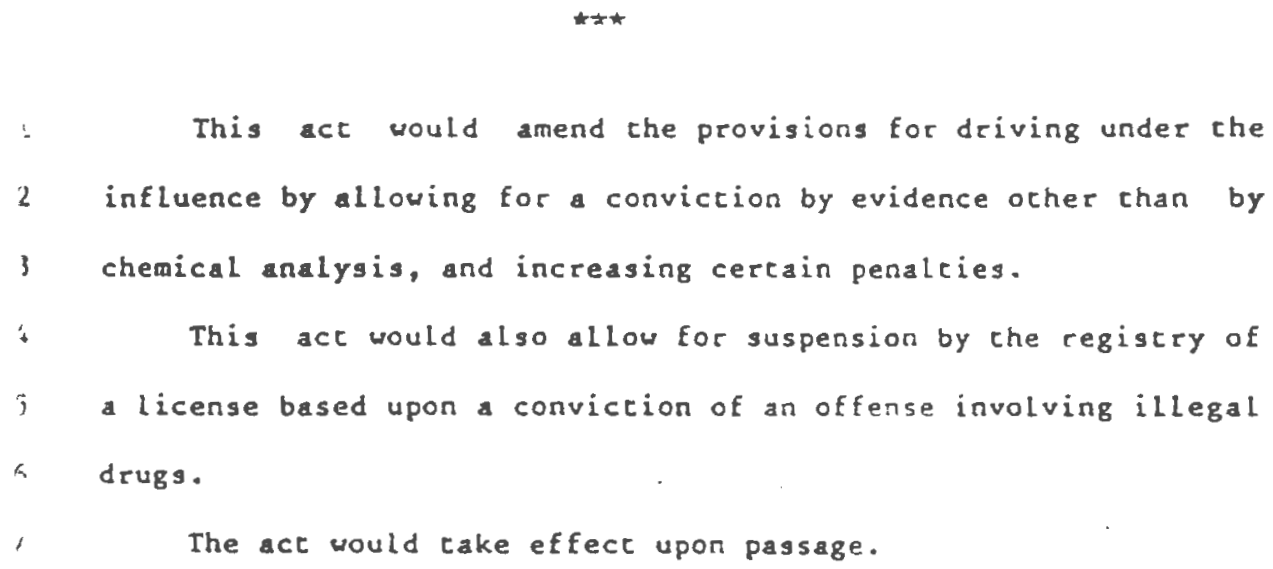




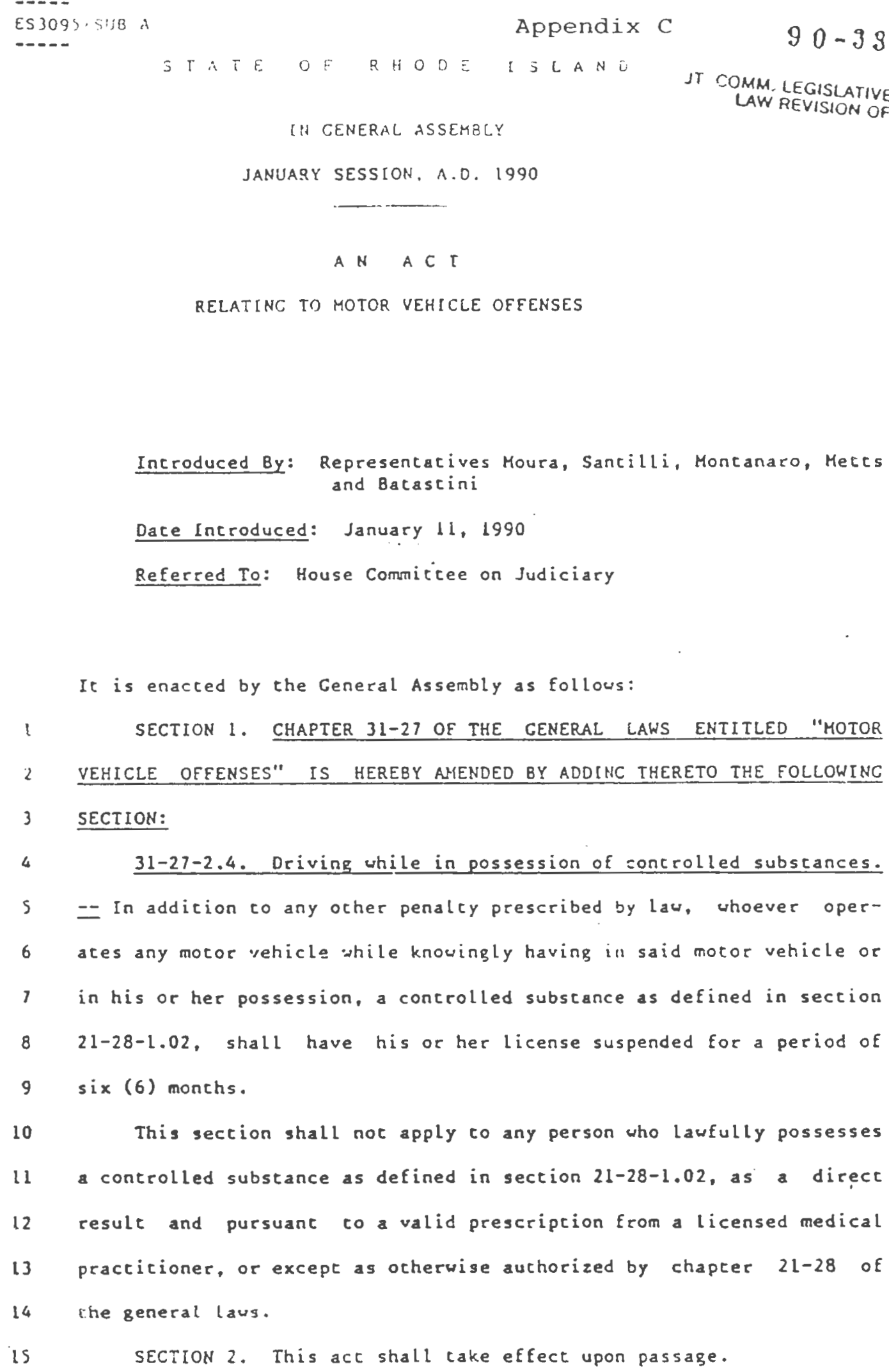

This section shall not apply to any person who lawfully possesses 
EXPLANATLON

BY THE LECISLATLVE COUTIOIL

OF

AN AST

RELATING TO MOTOR VEHICLE OFEENSES

$x \div \div$

1 This act would impose a six monch suspension or che license

2 of any person who operates any motor vehicle uhile knowingly hav-

3 ing in said mocor vehicle or in his or her possession a con-

4 trolled substance.

5 The act would take effect upon passage.

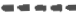

ES3095/SUB A

....- 
553095

EXPLATATION

BY IHE LECISLAIIVE COUNCIL

of

N ACT

RELATINC TO MOTOR VEHICLE OFFENSES

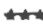

1 Thi, act would declare it a misemenor co operce a mocor

2 vehicl, while in che possession of a concrolled subsesce or pre-

3 Ictiption drug vichout a prescription, subject to a tial of

$4 \$ 50.00$ end woror vehicle license suspension for a period of cuo

5 years.

Tris ect would cake effect upon passage.

2 


$$
\begin{gathered}
90-994 \\
\text { IT COMM LEGISLATIVE SERVICGS } \\
\text { LAW RE:ISION OFFICE }
\end{gathered}
$$
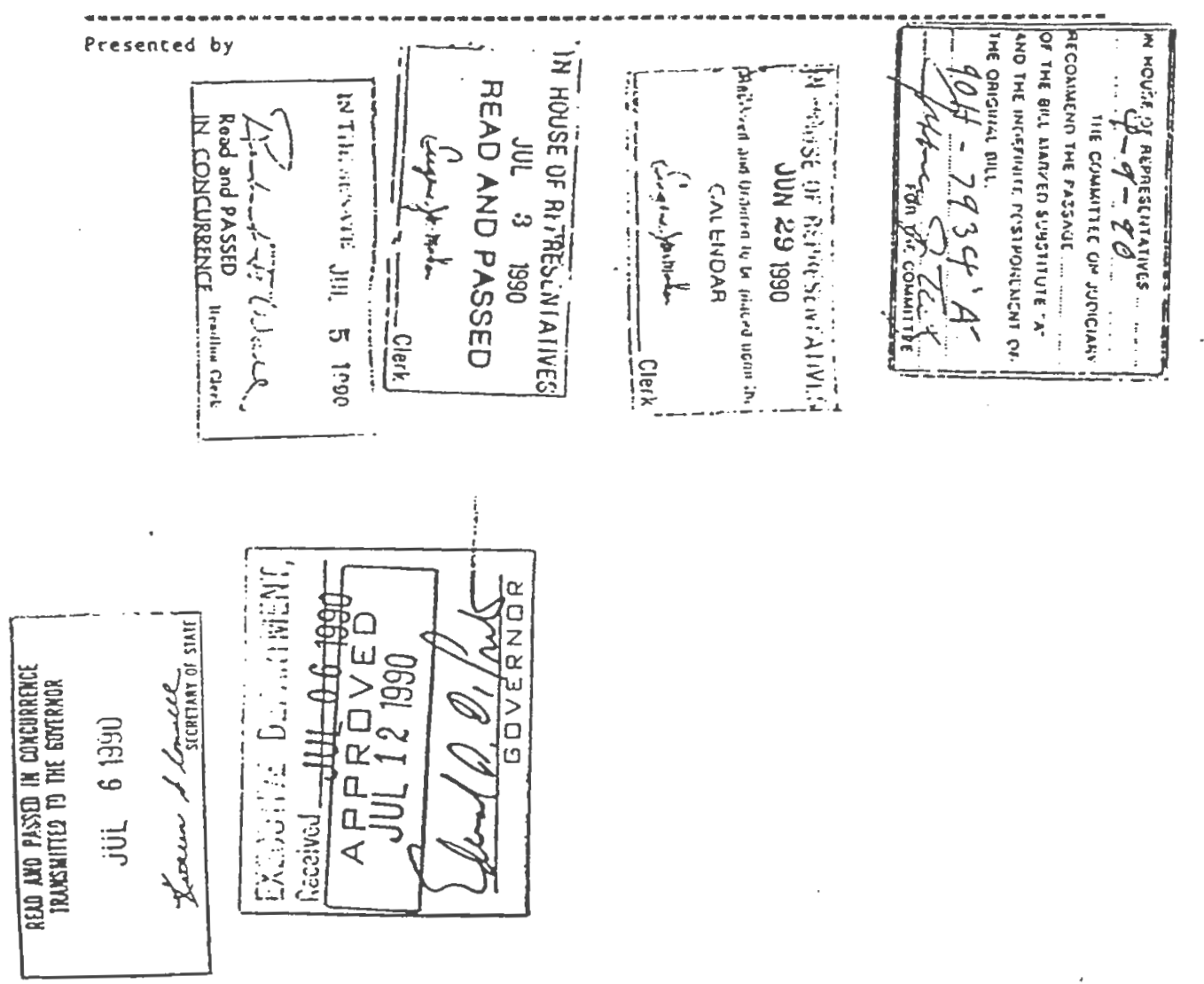


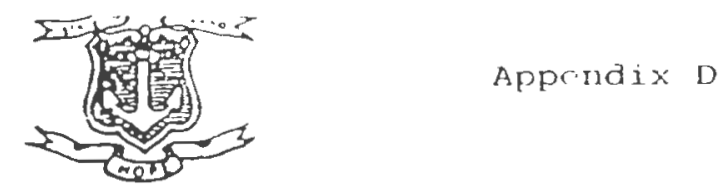

Uhe Bistrict Olourt of the State of Rhadr Boland

ALBERT E DOROBESO

CHE? MOSE

one oorrance PLAzA. PROVIOENCE. RHODE ISLAND 02903

April 12, 1993

Nicholas Scorobogaty

Instructor

Roger Williams University

612 Academy Avenue

Providence, RI 02908

Dear Mr. Scorobogaty:

In answer to your recent letter, the Rhode Island District Court has been made aware of the Drug Recognition Expert (DRE) program. In fact, we devoted an afternoon to the subject at our June, 1991 Annual Meeting. Our judges were very much interested in the program.

At that time, we had been led to believe that training programs for Rhode Island law enforcement officers were about to begin, under the auspices of the Department of Health. Whether that training has indeed taken place I do not know. I am aiso not aware of any case in Rhode Island in which DRE testimony has been specifically accepted under the expert testimony qualification procedures, either at the trial court or appellate court level.

Thank you for your interest in this area. .

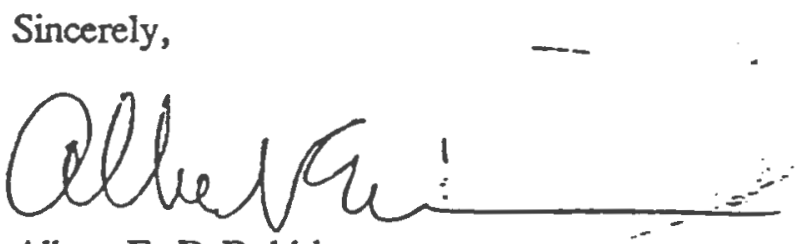

Albert E. DeRobbio

Chief Judge

AED/me 


\section{BIBLIOGRAPHY}

American Academy of Forensic Sciences. 1988. Current Status Report Drugs and Driving Committee.

Biasotti, A.A. "The Role of Forensic Scientist in the Application of Chemical Tests for Alcohol in Traffic Law Enforcement." Journal of Forensic Sciences, 29(4) (1984):1164-72.

Burns, M., H. Moskowitz. "Effects of Diphenhydramine an Alcohol on Skills Performance." European Journal of Clinical Pharmacology. 17(1980): 259-266.

Cary, P.L., et. al. "Driving Under the Influence of Phenobarbital." Journal of Forensic Sciences. 28(2) (1983):502-4.

Chiang, C.N., G. Barnett. "Marijuana effect an delta-9tetrahydrocannabinol plasma level." Clinical Pharmacology Therapeutics. 36(1984): 234-238.

Cimbura, G., et. al. "Incidence and Toxicological Aspects of Drugs detected in 484 fatally injured drivers and pedistrians in Ontario." Journal of Forensic Sciences. 27(4) (1982):855-67.

Clayton, R. C. "Drinking, Drug Use and Accidents: An Epidemiological Perspective." Alcohol, Drugs and Driving. 1(1-2) (1985): 115.

DOH,DDC, 1991 Breath Alcohol-Analysis Program.

DOH,DDC,1984 Drugged Driving Standards Survey 
Drug Concentration and Driving Impairment: A Consensus Report of the Panel. Journal of American Medical Association. 254(18) (1985): 26182621.

Dubowski, K.M. "Analysis of Drugs in biological fluids: state-of-theart. University of Oaklahoma." Alcohol Drugs and Traffic Safety II (1980): $433-41$.

Federal Register. Department of Health and Human Services. Scientific and Technical Guidelines for Federal Drug Testing Programs. 52(157) (1987): 1-4.

Fink III, J.L. "Driving Under the Influence of Medications." American Pharmacy. 5(29) (1989): 1989-1991.

Garriot, J.M. , N. Latham. "Drug Detection in cases of driving under the influence." Journal of Forensic Sciences. 21(1976):398-415.

General Laws of Rhode Island. 1956, as amended, Title 31, Chapter 27 , section 2(a).

Gengo, F. , C. Gabos, J. Miller. "The pharmacodynamics of diphenhydramine-induced drowsiness and changes in mental performance." Clinical Pharmacology Therapeutics. 45(1989):15-21.

Honkanen, Risto et. al. "Role of Drugs in Traffic Accidents." British Medical Journal. 281(1980):1309-12.

Hughes, F.W. , R.B. Forney. "Comparative effect of three Antihistamines and ethanol on mental and motor performance." Clinical Pharmacology Therapeutics. 6(1964): 414-421.

Jacknowitz, A.I. "When Drug Therapy and Driving Skills Don't Mix." U.S. Pharmacy. 11,29,64 (1964). 
Jick, Hershal. et. al. "Sedating Drugs and Automobile Accidents Hospitalization." American Journal of Public Health. 71 (1981): 1399 1400.G.

Klonoff, H. "Marijuana an Driving in Real-Life Situations." Science. 18(1974): 317-323.

Linnoila, M. , S. Hakkinen. "Effects of diazepam and codeine, alone and in combination of alcohol, on simulated driving." Clinical Pharmacology and Therapeutics. 14(1974):368-73.

Linnoila, M. , M. J. Mattila. "Interaction of alcohol and Drugs on psychomotor skills as demonstrated by a driving simulator." British Journal of Pharmacology. 47(1973):671-2.

Mason, A.P. , A. J. McBay. "Ethanol, Marijuana, and other Drug Use in 600 Drivers killed in single-vehicle crashes in North Carolina, 19781981." Journal of Forensic Sciences. 29(4) (1984): 987-1026.

McCurdy, H.H. et. al. "Incidence of Methaqualone in Driving-underthe-Influence (DUI) cases in Georgia." Journal of Analytical Toxicology. 5(1981):270-4.

Mellinger, G.D. , D. I. Manheiner, M. B. Balter. "Psycho-therapeutic drugs: Use among adults in California." California Medicine. 109(1968): 445-52.

Miller, Robert. "Investigation of the effects of Secobarbital on Cognitive and Psychomotor skills related to driving an Automobile." Thesis. (1981):1-57.

Neuteboom, W. , P. Zweipfennig. "Driving and the Combined use of alcohol in the Netherlands." Forensic Science International. 25(1984):18589.

Noordzij, P. C. , R. Roszbach. "Alcohol, Drugs and Driving." The First Symposium on Prescription Drugs and Driving Performance, Vinkenveer, the Netherlands. 1984. 
Rasaiah, B. "Blood Alcohol Testing." Canadian Medical Association Journal. 135(1986): 104-5.

Reeve, V. , et. al. "Hemolyzed Blood and Serum Levels of delta-9-THC: Effects on the Performance of Roadside Sobriety Tests." Journal of Forensic Sciences. 28(1983): 963-971.

Sharma, S. "Barbiturates and Driving." Accident analysis and Prevention. 8(1976):27-3.

Skegg, D.C.G. , S. M. Richards, R. Doll. Minor Tranquillisers and Road Accidents." British Medical Journal. 1(1979): 917-19.

Smith, L. , et. al. "The Interaction of Speed Instruction With Stimulus Quality and Diazepam in Choice Reaction Time Task." Alcohol, Drugs and Driving. 8(2) (1992): 107-119.

Stewart, K.G. , B.M. Sweedler, C.C. Hughes. Proceedings of the sectionAlcohol, Drugs and Traffic Safety of the 35th International Congress on Alcohol and Drug Dependence. Oslo, Norway, July 1988. National Clearinghouse for alcohol and Drug Information, Rockville, MD. 1988.

Stramer, G. "Antihistamines and Highway Safety." Accident Analysis and Prevention. 17(1985): 311-317. 1965.

Traffic Laws Commentary (Editorial): Drugs and Driving. 65-1, 1-17,

U.S. Department of Transportation. 5/93--Transportation Safety Institute--National Highway Traffic Safety Administration.

Valentour, J. "A survey of Drug use among Impaired Drivers in Virginia." Medico-Legal Bulletin(Virginia State Health Dept.). 29(1980):1-7.

Watts, V.W., T.F. Simonick, R.K. Cole. American Academy of Forensic Sciences, the Current Status Report, Drugs and Driving Committee. Colorodo Springs, CO. 1988. 
Williams, A.F., et. al. "Drugs in Fatally Injured Young Male Drivers." Public Health Reports. 100(1985):19-25.

Woodhouse, E. J. "The incidence of drugs in fatally injured drivers." U.S. Department of Transportation. 800(1975):411.

Zimmerman E.G. , et. al. "Measurement of Delta-9-

tetrahydrocannabinol (THC) in whole blood samples from impaired motorists." Journal of Science. 28(4) (1983):957-62. 